\title{
Improving the representation of secondary organic aerosol (SOA) in the MOZART-4 global chemical transport model
}

\author{
A. Mahmud and K. Barsanti \\ Department of Civil \& Environmental Engineering, Portland State University, P.O. Box 751-CEE, Portland, \\ OR 97207-0751, USA
}

Correspondence to: A. Mahmud (amahmud@pdx.edu)

Received: 29 October 2012 - Published in Geosci. Model Dev. Discuss.: 11 December 2012

Revised: 4 June 2013 - Accepted: 4 June 2013 - Published: 18 July 2013

\begin{abstract}
The secondary organic aerosol (SOA) module in the Model for Ozone and Related Chemical Tracers, version 4 (MOZART-4) was updated by replacing existing two-product $(2 \mathrm{p})$ parameters with those obtained from two-product volatility basis set (2p-VBS) fits (MZ4$\mathrm{C} 1$ ), and by treating SOA formation from the following additional volatile organic compounds (VOCs): isoprene, propene and lumped alkenes (MZ4-C2). Strong seasonal and spatial variations in global SOA distributions were demonstrated, with significant differences in the predicted concentrations between the base case and updated model simulations. Updates to the model resulted in significant increases in annual average SOA mass concentrations, particularly for the MZ4-C2 simulation in which the additional SOA precursor VOCs were treated. Annual average SOA concentrations predicted by the MZ4$\mathrm{C} 2$ simulation were $1.00 \pm 1.04 \mu \mathrm{g} \mathrm{m}^{-3}$ in South America, $1.57 \pm 1.88 \mu \mathrm{g} \mathrm{m}^{-3}$ in Indonesia, $0.37 \pm 0.27 \mu \mathrm{g} \mathrm{m}^{-3}$ in the USA, and $0.47 \pm 0.29 \mu \mathrm{g} \mathrm{m}^{-3}$ in Europe with corresponding increases of 178, 406, 311 and $292 \%$ over the base-case simulation, respectively, primarily due to inclusion of isoprene. The increases in predicted SOA mass concentrations resulted in corresponding increases in SOA contributions to annual average total aerosol optical depth (AOD) by 1-6\%. Estimated global SOA production was 5.8, 6.6 and 19.1 $\mathrm{Tg} \mathrm{yr}^{-1}$ with corresponding burdens of $0.22,0.24$ and $0.59 \mathrm{Tg}$ for the base-case, MZ4-C1 and MZ4-C2 simulations, respectively. The predicted SOA budgets fell well within reported ranges for comparable modeling studies, 6.7 to $96 \mathrm{Tg} \mathrm{yr}^{-1}$, but were lower than recently reported observationally constrained values, 50 to $380 \mathrm{Tg} \mathrm{yr}^{-1}$. For MZ4-C2, simulated SOA concentrations at the surface also were in reasonable agreement
\end{abstract}

with comparable modeling studies and observations. Total organic aerosol (OA) mass concentrations at the surface, however, were slightly over-predicted in Europe, Amazonian regions and Malaysian Borneo (Southeast Asia) during certain months of the year, and under-predicted in most sites in Asia; relative to those regions, the model performed better for sites in North America. Overall, with the inclusion of additional SOA precursors (MZ4-C2), namely isoprene, MOZART-4 showed consistently better skill (NMB (normalized mean bias) of -11 vs. $-26 \%$ ) in predicting total OA levels and spatial distributions of SOA as compared with unmodified MOZART-4. Treatment of SOA formation by these known precursors (isoprene, propene and lumped alkenes) may be particularly important when MOZART-4 output is used to generate boundary conditions for regional air quality simulations that require more accurate representation of SOA concentrations and distributions.

\section{Introduction}

Secondary organic aerosol (SOA) is formed through a series of oxidation reactions of precursor volatile organic compounds (VOCs) followed by partitioning of the oxidation products formed into particles based on their volatilities and activities (see for example, Pankow, 1994; Odum et al., 1996; Kavouras et al., 1998; Claeys et al., 2004; Kanakidou et al., 2005; Hallquist et al., 2009; and Jimenez et al., 2009). Organic aerosol (OA), a significant fraction of which is secondary, is a major component of fine particles throughout the atmosphere (Kanakidou et al., 2005). Such particles pose serious health risks (Schwartz, 2004; 
Delfino et al., 2005; Pope and Dockery, 2006) and affect the global radiative forcing budget (Andreae and Crutzen, 1997; Forster et al., 2007). Recently, Spracklen et al. (2011) estimated a global annual mean SOA production of 50$380 \mathrm{Tg} \mathrm{yr}^{-1}$ from both anthropogenic and biogenic sources, including isoprene using a "top-down" approach in which the estimates were constrained by measured data. "Bottomup" approaches, as employed in this study, generally result in lower estimates of global SOA production. In an early modeling study, Chung and Seinfeld (2002) estimated a global annual mean SOA production of $11.2 \mathrm{Tg} \mathrm{yr}^{-1}$ considering contributions solely from biogenic VOC precursors (excluding isoprene). Henze and Seinfeld (2006) showed that treating isoprene, which had been previously ignored, could nearly double the estimated global SOA production (from 8.7 to $16.4 \mathrm{Tg} \mathrm{yr}^{-1}$ ). Global mean SOA production of 53.4-68.8 $\mathrm{Tg} \mathrm{yr}^{-1}$ was estimated by Hoyle et al. (2009). More recently, Lin et al. (2012) reported estimated global SOA production of $90.8-120.5 \mathrm{Tg} \mathrm{yr}^{-1}$. The differences in global model estimates of SOA production between early and more recent models employing a bottom-up approach are largely due to changes in the identities and fluxes of the VOC precursors considered, as indicated above, and the SOA processes included, such as partitioning of primary OA and treatment of SOA aging (Lane et al., 2008; Murphy and Pandis, 2009; Farina et al., 2010). For the current generation of global chemical transport models, model-measurement comparisons show that while OA levels are in good agreement in certain areas (e.g., Heald et al., 2006; Slowik et al., 2010; Lin et al., 2012), models often produce under-estimates, both in the boundary layer (see for example, Johnson et al., 2006; Volkamer et al., 2006; Simpson et al., 2007; and Kleinman et al., 2008) and free troposphere (Heald et al., 2011). Heald et al. (2011) showed that though the latest generation of the global chemical transport model GEOS-Chem (Goddard Earth Observing System-Chem) captured general trends in vertical profiles, OA levels were under-estimated in the free troposphere (between $\sim 2-6 \mathrm{~km}$ above ground) in 13 out of 17 field campaigns.

The under-prediction of total OA levels by global (and regional) chemical transport models is typically attributed to under-prediction of SOA (see for example, Jimenez et al., 2009). The under-prediction of SOA in the atmosphere largely is a consequence of simplified model parameterizations that include a limited number of parent VOCs, as well as an incomplete understanding and representation of the principal mechanisms and products that contribute to SOA formation under ambient conditions. Accurate representations of precursor species and their reactions/reaction products are critical for predicting SOA concentrations in the atmosphere. Thus, there have been numerous efforts to improve SOA parameterizations for regional and global models (Donahue et al., 2006; Pankow and Barsanti, 2009; LeeTaylor et al., 2011; Murphy et al., 2011; Valorso et al., 2011). Following the trend in SOA model improvements, one of the objectives of this work was to employ updated SOA parameterizations in the global chemical transport model, MOZART-4 (Model for Ozone and Related Chemical Tracers, version 4) (Emmons et al., 2010).

MOZART has been employed to estimate global abundance and budgets of air pollutants such as ozone $\left(\mathrm{O}_{3}\right)$ (Emmons et al., 2010) and OA (Lack et al., 2004), and to study source attributions (Wespes et al., 2012) and longrange transport (e.g., Park et al., 2009; Pfister et al., 2010; Clarisse et al., 2011) of trans-boundary pollutants. MOZART is also frequently used to generate boundary conditions (BCs) in regional modeling studies (see for example, Dunlea et al., 2009; Tang et al., 2009; and Herron-Thorpe et al., 2012); these studies have shown that MOZART-derived dynamic BCs generally improve predictions. The current public-release version of MOZART (MOZART-4) calculates SOA based on early two-product (2p) parameterizations of chamber data for a limited number of precursor VOC species. The objectives of the current study were to update the SOA module in MOZART-4 by replacing existing $2 p$ parameters with those obtained from $2 p$ volatility basis set ( $2 p-V B S)$ fits, and to treat additional anthropogenic and biogenic VOCs that are known SOA precursors. It is expected that with the revised SOA parameters and inclusion of relevant SOA precursors, SOA predictions by MOZART (and similarly configured chemical transport models) can be significantly improved, one important consequence of which will be an improvement in MOZART-derived BCs used in regional air quality modeling studies.

\section{Methods}

Detailed descriptions of the modeling system and updates to MOZART-4 from previous versions can be found elsewhere (Emmons et al., 2010). Here a brief description of the model and updates to the SOA module are presented.

\subsection{Description of the MOZART-4 model}

The Model for Ozone and Related Chemical Tracers, version 4 is an offline global chemical transport model particularly well suited for studies of the troposphere (Emmons et al., 2010). MOZART-4 has been developed at the National Center for Atmospheric Research (NCAR) and includes a number of updates over the previous version, MOZART-2 (Horowitz et al., 2003). The modeling framework of MOZART is based on an initial model of atmospheric chemistry and transport (MATCH) developed by Rasch et al. (1997). The treatment of physical processes including convective mass flux (Hack, 1994), vertical diffusion within boundary layer (Holtslag and Boville, 1993), wet deposition (Brasseur et al., 1998), and advective transport (Lin and Rood, 1996) in the current version of MOZART have not been updated from MOZART-2. However, the gas-phase 
chemical mechanism has been significantly improved in MOZART-4. Tables 2 and 3 in Emmons et al. (2010) explicitly list the model species and gas-phase reactions. There are 85 gas-phase species, 12 bulk aerosol compounds, 39 photolysis and 157 gas-phase reactions in MOZART- 4 .

The aerosol model in MOZART-4 has been adapted from the work of Tie et al. (2001, 2005). The model includes calculations of sulfate, black carbon, primary organic carbon (i.e., POA) and secondary organic carbon (i.e., SOA), ammonium nitrate and sea salt (Lamarque et al., 2005). The black and organic carbon aerosols are calculated from both hydrophilic and hydrophobic fractions (Chin et al., 2002). Sulfate aerosols are calculated from $\mathrm{SO}_{2}$ and dimethyl sulfide emissions (Barth et al., 2000). Uptake of gas-phase $\mathrm{N}_{2} \mathrm{O}_{5}$, $\mathrm{HO}_{2}, \mathrm{NO}_{2}$ and $\mathrm{NO}_{3}$ are allowed (Jacob, 2000), and the hygroscopic growth of the aerosol is determined from the ambient relative humidity (Chin et al., 2002). The washout of all aerosols is set to $20 \%$ of the washout of nitric acid. The bulk aerosol parameters used in calculation of surface area are provided in Table 6 of Emmons et al. (2010).

MOZART-4 calculates photolysis rates online using the fast-TUV (FTUV) scheme based on the TUV (Tropospheric Ultraviolet-Visible) model that takes into account the impact from clouds and aerosols (Tie et al., 2003). The dry deposition of gas- and particle-phase species is also determined online using resistance-based parameterizations of vegetation. In the current study, the SOA module in MOZART-4 was revised as described below; simulations were carried out for a base case and two cases with module updates.

\subsection{Revisions to SOA module}

The formation of SOA in MOZART-4 is linked to gas-phase chemistry through oxidation of various precursor VOCs (e.g., Chung and Seinfeld, 2002) including lumped monoterpenes $\left(\mathrm{C}_{10} \mathrm{H}_{16}\right.$ as $\alpha$-pinene), lumped aromatics (TOLUENE), and lumped alkanes with carbon numbers great than $3,>\mathrm{C} 3$ (BIGALK as $\mathrm{C}_{5} \mathrm{H}_{12}$ ) through oxidation by hydroxyl radical $(\mathrm{OH})$, ozone $\left(\mathrm{O}_{3}\right)$ and/or nitrate radical $\left(\mathrm{NO}_{3}\right)$. SOA formation is based on the Odum $2 \mathrm{p}$ model (Odum et al., 1996), where up to two products are formed through the gasphase reactions of each precursor (PARENT) VOCs + oxidant (OXIDANT), that can subsequently partition into the particle phase:

PARENT + OXIDANT $\rightarrow \alpha_{1}$ PROD $_{1}+\alpha_{2}$ PROD $_{2}$.

The gas/particle partitioning of each lumped product (e.g., $\mathrm{PROD}_{1}$ and $\mathrm{PROD}_{2}$ ) is based on the fundamental theory developed by Pankow (1994). In the current version of the model, based on Lack et al. (2004), the lumped products partition into an existing organic aerosol mass $\left(M_{\mathrm{o}}\right)$, thus the partitioning is not treated iteratively. The model also assumes that the formation of SOA is irreversible, i.e., the model does not allow evaporation of SOA from the particle phase once formed. SOA yields $\left(Y_{\mathrm{p}}\right)$ are derived instantaneously using
Eq. (2) and are dependent on the $M_{\mathrm{o}}$ that exists at that time step:

$Y_{\mathrm{p}}=M_{\mathrm{o}} \sum_{i}\left(\frac{\alpha_{i} K_{\mathrm{p}, i}}{1+K_{\mathrm{p}, i} M_{\mathrm{o}}}\right)$.

The fractional yield $\left(\alpha_{i}\right)$ of each lumped VOC oxidation product and partitioning coefficients $\left(K_{\mathrm{p}, i}\right)$ are obtained from the literature. The initial mass of organic aerosol, $M_{\mathrm{o}}$, is calculated from both "hydrophilic" and "hydrophobic" components of organic carbon (OC). If $M_{\mathrm{o}}$ is less than or equal to $0.2 \mu \mathrm{g} \mathrm{m}^{-3}$ then the yield is calculated using the bulk-yield technique (Lack et al., 2004), otherwise the yield is calculated using the partitioning theory described by the above equation.

For the base case, the existing $2 p$ parameters for each of the default parent VOC species in the model were normalized for particle density of $1 \mathrm{~g} \mathrm{~cm}^{-3}$ and a standard temperature of $298 \mathrm{~K}$. Then, for case 1 , the SOA module was modified by replacing the existing $2 p$ parameters with $2 p-$ VBS parameters (see supporting information for derivation technique of 2p-VBS parameters). The MOZART-4 simulations employing the 2p-VBS parameters henceforth will be referred to as MZ4-C1. For case 2, three additional SOA precursor species, not previously considered, were added in the SOA module. The newly treated species were the biogenic precursor isoprene (ISOP), and the anthropogenic precursors propene $\left(\mathrm{C}_{3} \mathrm{H}_{6}\right)$ and $>\mathrm{C} 3$ lumped alkenes (BIGENE as $\mathrm{C}_{4} \mathrm{H}_{8}$ ). The MOZART-4 simulations including the newly treated VOCs will henceforth be referred to as MZ4-C2. Table 1 contains the list of the base-case and 2p-VBS parameters for the MOZART-4 default precursor species and newly treated species (with the exception of isoprene, for which the parameters of Henze and Seinfeld (2006) were used and monoterpene oxidation by $\mathrm{NO}_{3}$, for which the parameters of Chung and Seinfeld (2002) were used). Note that the parameters provided in Table 1 are for particle density of $1 \mathrm{~g} \mathrm{~cm}^{-3}$ and temperature of $298 \mathrm{~K}$ and are based on high $\mathrm{NO}_{\mathrm{x}}$ pathways (anthropogenic precursors and monoterpenes) to be consistent with the default MOZART-4 parameters.

The $2 p$-VBS parameters were conceived in order to take advantage of the robustness of the volatility basis set (VBS) fitting approach (e.g., see Presto and Donahue, 2006), while allowing the computationally efficient and widely used $2 \mathrm{p}$ modeling framework to be retained. The parameters were derived by (1) using VBS fits (Tsimpidi et al., 2010) to generate pseudo-data, and (2) fitting the pseudo-data using the $2 p$ approach (Odum et al., 1996). Each of the VBS parameters of Tsimpidi et al. (2010) at $T=298 \mathrm{~K}$ were used to generate 263 pseudo-data points for $M_{\mathrm{o}}=0$ to $200 \mu \mathrm{g} \mathrm{m}^{-3}$ at each of three temperatures $(272,298$, and $324 \mathrm{~K})$ using an effective $\Delta H_{\text {vap }}=30 \mathrm{~kJ} \mathrm{~mol}^{-1}$ (see Pathak et al., 2007); those 789 pseudo-data points were then fit to generate one set of $2 p$ parameters (per set of VBS parameters), thus labeled "2p-VBS". For each of the SOA precursors, the 2p-VBS 
Table 1. Base-case and revised SOA parameters (MZ4-C1) for original and newly treated parent VOCs (MZ4-C2) in MOZART-4. Base-case parameters are the default model parameters normalized for $\rho=1.0 \mathrm{~g} \mathrm{~cm}^{-3}$ and $T=298 \mathrm{~K}$. Revised parameters also are for $\rho=1.0 \mathrm{~g} \mathrm{~cm}-3$ and $T=298 \mathrm{~K}$ and are based on $2 \mathrm{p}-\mathrm{VBS}$ fits with the exception of $\mathrm{NO}_{3}$ oxidation of monoterpenes and $\mathrm{OH}$ oxidation of isoprene, which are based on Chung and Seinfeld (2002) and Henze and Seinfeld (2006), respectively.

\begin{tabular}{llrrrr}
\hline Parent VOC MOZART-4 (SAPRC 99) & Oxidant & $\alpha_{1}$ & $K_{p 1}$ & $\alpha_{2}$ & $K_{p 2}$ \\
\hline Base-Case VOCs & & & & & \\
\hline $\mathrm{C}_{10} \mathrm{H}_{16}^{\mathrm{a}}$ (TERP) & $\mathrm{O}_{3} / \mathrm{OH}$ & 0.354 & 0.0043 & 0.067 & 0.184 \\
$\mathrm{C}_{10} \mathrm{H}_{16}^{\mathrm{a}}$ (TERP) & $\mathrm{NO}_{3}$ & 1.000 & 0.016 & 0.000 & 0.000 \\
TOLUENE $^{\mathrm{b}}$ (ARO1) & $\mathrm{OH}$ & 0.167 & 0.002 & 0.038 & 0.069 \\
BIGALK $^{\mathrm{c}}$ (ALK3+ALK4+ALK5) & $\mathrm{OH}$ & 0.138 & 0.003 & 0.071 & 0.087 \\
\hline $\mathrm{MZ4-C1} \mathrm{VOCs}$ & & & & & \\
\hline $\mathrm{C}_{10} \mathrm{H}_{16}^{\mathrm{a}}$ (TERP) & $\mathrm{O}_{3} / \mathrm{OH}$ & 0.289 & 0.008 & 0.086 & 0.205 \\
$\mathrm{C}_{10} \mathrm{H}_{16}^{\mathrm{a}}$ (TERP) & $\mathrm{NO}_{3}$ & 1.000 & 0.016 & 0.000 & 0.000 \\
TOLUENE $^{\mathrm{b}}$ (ARO1) & $\mathrm{OH}$ & 0.325 & 0.008 & 0.124 & 0.146 \\
$\mathrm{BIGALK}^{\mathrm{c}}$ (ALK3+ALK4+ALK5) & $\mathrm{OH}$ & 0.100 & 0.150 & 0.047 & 0.080 \\
\hline VOCs Added in MZ4-C2 & & & & & \\
\hline ISOP (ISOPRENE) $_{\mathrm{C}_{5} \mathrm{H}_{8}(\mathrm{OLE} 1)}$ & $\mathrm{OH}$ & 0.178 & 0.011 & 0.022 & 2.106 \\
BIGENE $^{\mathrm{d}}$ (OLE2) & $\mathrm{OH}$ & 0.078 & 0.005 & 0.006 & 0.167 \\
\hline
\end{tabular}

${ }^{a}$ lumped monoterpenes as $\alpha$-pinene; ${ }^{b}$ lumped aromatics as toluene; ${ }^{c}$ lumped alkanes with $\mathrm{C}>3$ as $\mathrm{C}_{5} \mathrm{H}_{12}$;

d lumped alkenes with $\mathrm{C}>3$ as $\mathrm{C}_{4} \mathrm{H}_{8}$.

parameters were able to represent SOA formation with the same degree of uncertainty as the VBS parameters (i.e., no additional error is introduced by the 2p-VBS fit). It therefore can be assumed that the SOA yield and mass predictions using the Tsimpidi et al. (2010) VBS parameters and the 2pVBS parameters produce equivalent results (in the absence of any "aging"), including temperature dependent SOA yields. The $2 \mathrm{p}$-VBS fits result in a reduction from 4 "bins" ( 8 parameters, typical for VBS) to 2 bins (4 parameters), which can be utilized in existing $2 \mathrm{p}$ model frameworks, such as MOZART. The MOZART SOA module does not allow for aging or processing of SOA, thus the gas-phase oxidation (beyond the initial oxidation of the parent VOC) that is often represented in applications of the VBS is not considered in this work. For the precursors included in the MOZART simulations, it was determined that the $2 \mathrm{p}$-VBS parameters represented available chamber data well, with the exception of isoprene. Therefore, the parameters of Henze and Seinfeld (2006) were used. In addition, the MOZART SOA module includes oxidation of monoterpenes by $\mathrm{NO}_{3}$ for which Tsimpidi et al. (2010) VBS parameters, and thus 2p-VBS parameters, are not available. The monoterpene+NO3 parameters were based on Chung and Seinfeld (2002). The development, testing, and application of 2p-VBS parameters are presented in Barsanti et al. (2013).

\subsection{Model simulations}

In the current study, the MOZART-4 source code was downloaded from the University Cooperation for Atmospheric Research (UCAR) website (http://cdp.ucar.edu). All model simulations were carried out for the entire year of 2006, and the monthly averages were analyzed. Anthropogenic emissions used for the simulation in the current study came from the POET (Precursors of Ozone and their Effects in the Troposphere) dataset for 2000 (Olivier et al., 2003; Granier et al., 2005). Monthly average biomass burning emissions were from the Global Fire Emissions Database, version 2 (GFED-v2) (van der Werf et al., 2006). Biogenic emissions of monoterpenes and isoprene are calculated online in MOZART-4 using the Model of Emissions of Gases and Aerosols from Nature (MEGAN) (Guenther et al., 2006). As described in Emmons et al. (2010) the surface and upper boundary concentrations of long-lived species (e.g., $\mathrm{CH}_{4}$ and $\mathrm{N}_{2} \mathrm{O}$ ) were obtained from ground- and satellite-based measurements.

MOZART-4 was driven by meteorology from the NCAR reanalysis of the National Centers for Environmental Prediction (NCEP) forecasts (Kalnay et al., 1996; Kistler et al., 2001), at a horizontal resolution of $\sim 2.8^{\circ} \times 2.8^{\circ}$, with 28 vertical levels from the surface to $\sim 2.7 \mathrm{hPa}$. This gives a standard resolution of $128 \times 64$ grid boxes with 28 vertical layers. 


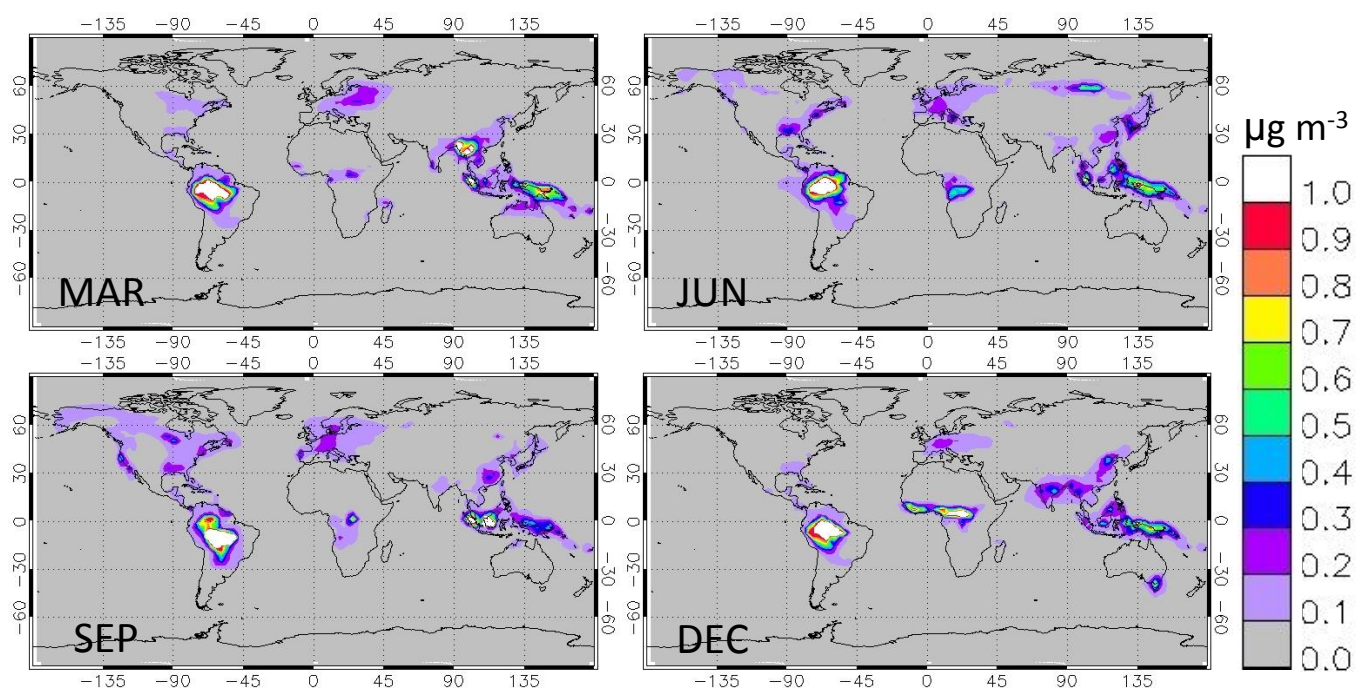

Fig. 1. Global distributions of monthly average SOA concentrations $\left(\mu \mathrm{g} \mathrm{m}^{-3}\right)$ at the surface predicted in the base-case MOZART-4 runs for March, June, September and December of 2006.

\section{Results and discussion}

In this section, analyses from the base-case and updated MOZART-4 simulations are presented, followed by comparisons with observations and previous modeling studies. Note that the first month of each simulation was excluded from the analysis to account for model spin-up time. There is no direct measurement of SOA as a component of total OA, thus observational data for global SOA levels are essentially non-existent. Previous studies (see for example, Lack et al., 2004; Heald et al., 2006; Liao et al., 2007; Farina et al., 2010; Jiang et al., 2012; and Lin et al., 2012) have compared modeled SOA to SOA determined indirectly from total OA measurements. Some of these studies have also compared modeled SOA with reported SOA levels from relevant modeling studies. It is important to recognize that both of these techniques, comparing modeled levels with indirect determinations and/or with other modeling studies, have limitations. For example, most of the measurements are taken at specific locations over a short period of time that often do not capture the range of conditions including the influence of local emissions represented in a simulated grid, which is typically in the order of degrees (latitude $\times$ longitude) in a global chemical transport model. This makes the comparison of a global chemical transport model output with observations quite challenging.

Quantification and characterization of sources of organic aerosol have always been challenging, particularly, due to utilization of different thermal-optical organic carbon quantification and artifact removal techniques, and handing of sampling and analytical errors including determination of sample cut sizes and detection limits. SOA concentrations are often determined indirectly using the EC tracer technique, which also could contribute to compounding errors in comparisons between modeled vs. calculated SOA because of the range of the $\mathrm{EC}$ : OC ratio that can be utilized in the calculation. Regarding model to model comparisons, model predictions are also subject to errors that primarily evolve from uncertainties in emissions, meteorology, and physical and chemical parameterization techniques unique to each chemical transport model. Nevertheless, such comparisons are necessary for model development and validation.

\subsection{Modeled SOA concentrations}

\subsubsection{Surface concentrations}

Figure 1 shows global temporal and spatial distributions of monthly average SOA concentrations $\left(\mu \mathrm{g} \mathrm{m}^{-3}\right)$ at the surface produced by the base-case simulations. SOA of $>1.0 \mu \mathrm{g} \mathrm{m}^{-3}$ is predicted in heavily forested regions including the Amazonian region in South America, equatorial regions in Africa, and rainforest regions in Southeast Asia. The highest amount of SOA, $\sim 3.0 \mu \mathrm{g} \mathrm{m}^{-3}$, was predicted in the Amazonian region during the month of September, followed by $\sim 2.0 \mu \mathrm{g} \mathrm{m}^{-3}$ in Indonesia during the month of September and $\sim 2.0 \mu \mathrm{g} \mathrm{m}^{-3}$ in the equatorial region in Africa in December. The Amazonian region generally experienced $\sim 0.6-2.0 \mu \mathrm{g} \mathrm{m}^{-3}$ of SOA in other months including March, June and December. (The highest monthly concentration, $\sim 9.0 \mu \mathrm{g} \mathrm{m}^{-3}$ in August, was predicted in the Amazonian region and is not shown in Fig. 1.) Similarly, the rainforest regions in Southeast Asia experienced $\sim 0.4-1.0 \mu \mathrm{g} \mathrm{m}^{-3}$ of SOA during the months of March, June and December. The base-case model predicted $\sim 0.2-0.8 \mu \mathrm{g} \mathrm{m}^{-3}$ of SOA in the equatorial regions in Africa for months other than December. SOA concentrations of $\sim 0.2-0.6 \mu \mathrm{g} \mathrm{m}^{-3}$ were predicted 

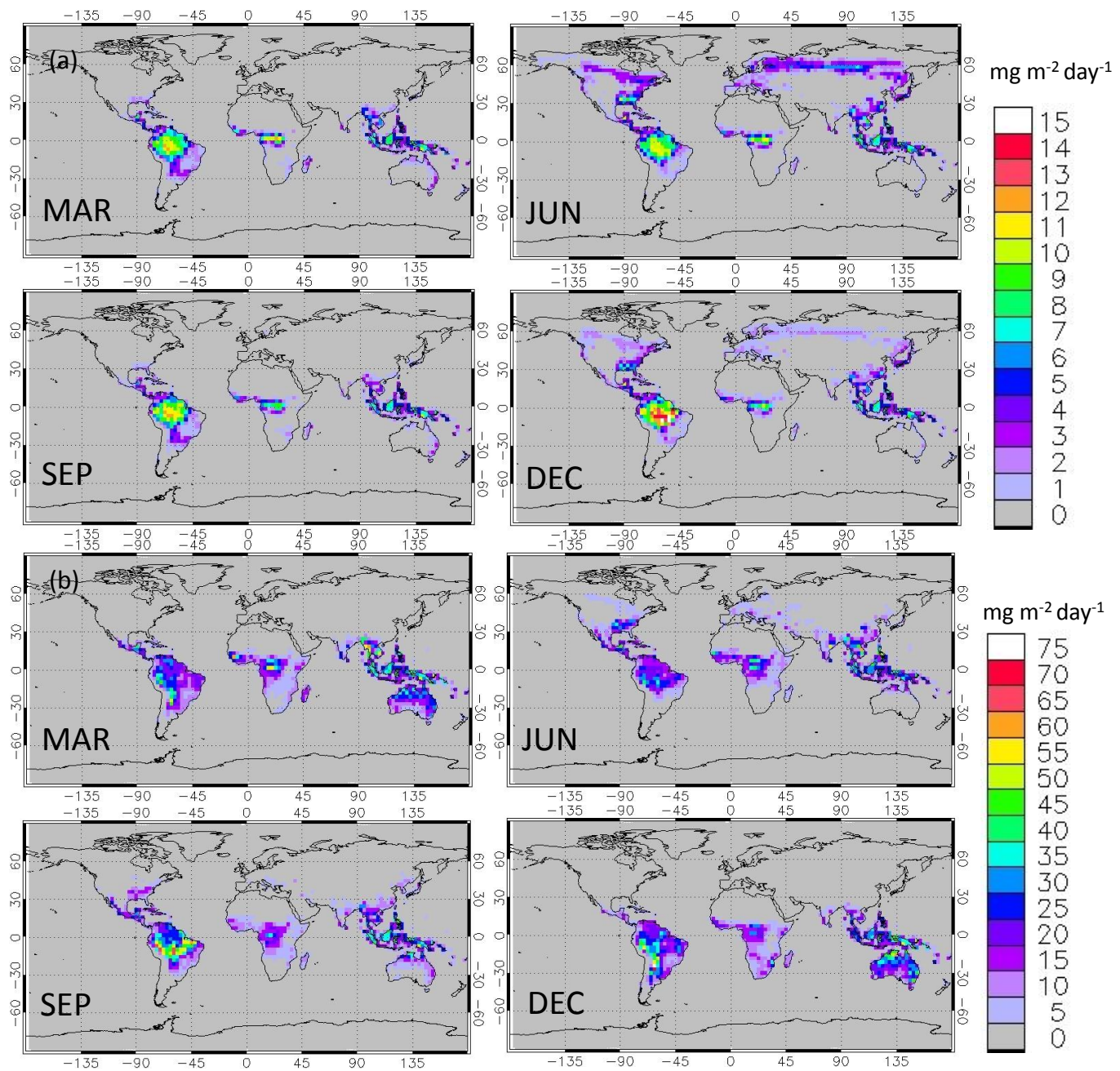

Fig. 2. Global distributions of monthly average emission rates $\left(\mathrm{mg} \mathrm{m}^{-2} \mathrm{day}^{-1}\right)$ for (a) summed monoterpenes $\left(\mathrm{C}_{10} \mathrm{H}_{16}\right)$, and $(\mathbf{b})$ isoprene $\left(\mathrm{C}_{5} \mathrm{H}_{8}\right)$ at the surface. Examples are shown for representative months in different seasons of the year.

in the eastern and western parts of the USA only during the months of June and September. Western Europe consistently experienced $\sim 0.2 \mu \mathrm{g} \mathrm{m}^{-3}$ of SOA formation throughout the year. In southern and eastern China, predicted SOA concentrations varied between $\sim 0.2$ and $\sim 1.4 \mu \mathrm{g} \mathrm{m}^{-3}$ throughout all seasons. SOA of $\sim 0.2 \mu \mathrm{g} \mathrm{m}^{-3}$ was predicted over the Indian subcontinent only in December. It is important to note that the global distribution of SOA is primarily dominated by the SOA precursors emitted from biogenic sources, which can be seen from the distributions of precursor VOC emissions as discussed in the following paragraphs.

Figure $2 \mathrm{a}$ and $\mathrm{b}$ show global distributions of monthly average surface emissions rates $\left(\mathrm{mg} \mathrm{m}^{-2} \mathrm{day}^{-1}\right)$ of summed monoterpenes $\left(\mathrm{C}_{10} \mathrm{H}_{16}\right)$ and isoprene $\left(\mathrm{C}_{5} \mathrm{H}_{8}\right)$, respectively. The plots reveal that emissions are higher in the Amazonian region in South America, mid-Africa near the Equator, northeastern and southeastern USA, western Europe, Southeast Asia, southern and eastern China, and Australia compared to other parts of the world. Monoterpene emissions in South America vary between $\sim 6$ and $14 \mathrm{mg} \mathrm{m}^{-2}$ day $^{-1}$ throughout the year, with highest emissions occurring during the Southern Hemisphere spring (September) and summer (December) months. Consequently, the base-case model also predicted higher amounts of SOA in these regions (Fig. 1) during these months. Emissions in mid-Africa, Southeast Asia, and Australia vary between $\sim 2$ and $8 \mathrm{mg} \mathrm{m}^{-2}$ day $^{-1}$ throughout the year. Regions in North America and Europe emit relatively lower amounts of monoterpenes, $<1 \mathrm{mg} \mathrm{m}^{-2}$ day $^{-1}$ for spring (March) and winter (December) months, and $\sim 1-$ $6 \mathrm{mg} \mathrm{m}^{-2}$ day $^{-1}$ for summer (June) and fall (September) months.

Isoprene emissions follow similar spatial and temporal distributions to monoterpenes. Emissions in South American regions vary from $\sim 8$ to $56 \mathrm{mg} \mathrm{m}^{-2}$ day $^{-1}$, with the highest levels occurring in their spring month. Isoprene emissions over the Australian continent can be significant, especially in 


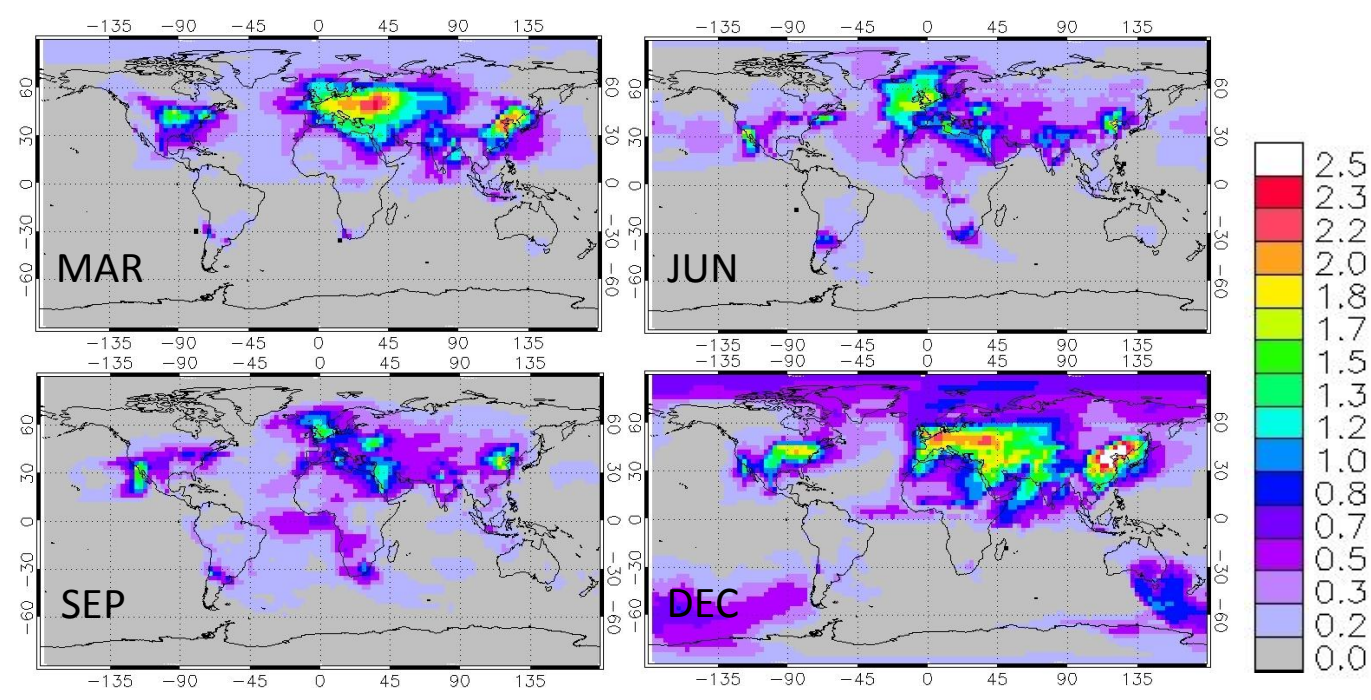

Fig. 3. Fractional change in simulated surface SOA concentrations due to $2 p$ parameter updates (MZ4-C1) relative to the base case.

their summer and fall months when the emissions are $\sim 10$ $40 \mathrm{mg} \mathrm{m}^{-2} \mathrm{day}^{-1}$. Consistent emissions of isoprene are also found in Southeast Asian regions throughout the year, at rates of $\sim 8-28 \mathrm{mg} \mathrm{m}^{-2} \mathrm{day}^{-1}$. Generally, isoprene emissions are 4 to 5 times higher than the emissions of monoterpenes; thus even with a relatively low SOA yield (e.g., Lee et al., 2006), the treatment of isoprene as an SOA precursor (as in MZ4C2) has the potential to substantially change SOA simulations, likely improving global and regional SOA predictions (the latter when MOZART-4 is used to generate boundary conditions).

The amount of SOA produced in the atmosphere largely depends on the concentration of precursors, availability of oxidants, and SOA yields for each of the precursor species; additionally, SOA yields depend on the amount of existing organic aerosol into which compounds can condense. Temperature can also play an important role in partitioning of semi-volatile organics between the gas and particle phase; cold temperatures aloft particularly favor gas-phase product condensation into particles. Global surface emissions of primary organic aerosol (POA) and SOA precursors utilized in the current work are given in Table 2. A POA emission rate of $63 \mathrm{Tg} \mathrm{yr}^{-1}$ was used for all MOZART-4 simulations, including the base case. The total SOA precursor emissions were significantly higher in the MZ4-C2 simulation than in the MZ4-C1 and base-case simulations, due to the consideration of isoprene, BIGENE and $\mathrm{C}_{3} \mathrm{H}_{6}$. The sum of VOC emissions acting as SOA precursors was $676 \mathrm{Tg} \mathrm{yr}^{-1}$ in MZ4$\mathrm{C} 2$, and $199 \mathrm{Tg} \mathrm{yr}^{-1}$ in $\mathrm{MZ} 4-\mathrm{C} 1$ and the base case. Biogenic sources constituted $\sim 82$ and $\sim 45 \%$, respectively, of the total SOA precursor emissions; of the $82 \%$ in MZ4C2, isoprene (ISOP) accounted for $\sim 84 \%$ (with summed monoterpenes accounting for the remaining $16 \%$ ). Lumped alkanes (BIGALK), with an emission rate of $77 \mathrm{Tg} \mathrm{yr}^{-1}$, were the dominant parent VOC from anthropogenic sources followed by lumped aromatics (TOLUENE: $33 \mathrm{Tg} \mathrm{yr}^{-1}$ ), lumped alkenes (BIGENE: $\left.9 \mathrm{Tg} \mathrm{yr}^{-1}\right)$ and propene $\left(\mathrm{C}_{3} \mathrm{H}_{6}\right.$ : $6 \mathrm{Tg} \mathrm{yr}^{-1}$ ).

The change in SOA $(\triangle \mathrm{SOA})$ predicted by MZ4-C1 and MZ4-C2 was calculated as a fractional change from the base case. Figure 3 shows the distribution of the fractional change in SOA relative to the base case as predicted by MZ4-C1. Utilization of the 2p-VBS parameters resulted in significant increases in SOA over the USA in North America, western and central Europe, and eastern China in Asia. Monthly average SOA in these regions increased by $\sim 1-$ 2 times $(\sim 100-200 \%)$ throughout the year with slightly higher increases $(\sim 200-250 \%)$ in the month of December. Generally, the base-case SOA concentrations in these regions was $<1 \mu \mathrm{g} \mathrm{m}^{-3}$. A consistent SOA increase of $\sim 50 \%$ in the months of September and December was seen in the South American and mid-African regions, where the base-case SOA was in the range of $\sim 2-3 \mu \mathrm{g} \mathrm{m}^{-3}$ for those months. Increased SOA in continental North America, Europe, and Asia indicates that anthropogenic precursors such as toluene (TOLUENE) and lumped alkanes (BIGALK) can lead to significant SOA formation, even as represented in a global model, depending on the parameters used. SOA production nearly mimics the pattern of emissions, i.e., SOA is predominantly formed where the emission sources are. Monoterpenes in the southeast coastal regions of Australia are emitted at a rate of $\sim 1.0 \mathrm{mg} \mathrm{m}^{-2}$ day $^{-1}$ in the summer month of December, which resulted in SOA mass concentration of up to $0.23 \mu \mathrm{g} \mathrm{m}^{-3}$. SOA mass enhancement (as shown in Fig. 3) in close proximity to this region likely was a consequence of using the 2p-VBS parameters. However, apparent SOA enhancement farther from this region could be attributed to model artifacts, like the enhancements in the far 
Table 2. Global surface emissions of POA and SOA precursors from anthropogenic and biogenic sources.

\begin{tabular}{|c|c|}
\hline Type/Species & Emissions $\left(\mathrm{Tg} \mathrm{yr}^{-1}\right)$ \\
\hline POA (hydrophobic + hydrophilic)* & 63 \\
\hline \multicolumn{2}{|l|}{ Anthropogenic } \\
\hline TOLUENE $\left(\mathrm{C}_{7} \mathrm{H}_{8}\right.$ : lumped aromatics $)$ & 33 \\
\hline $\operatorname{BIGALK}\left(\mathrm{C}_{5} \mathrm{H}_{12}\right.$ : lumped alkanes with $\left.\mathrm{C}>3\right)$ & 77 \\
\hline BIGENE $\left(\mathrm{C}_{4} \mathrm{H}_{8}\right.$ : lumped alkenes with $\left.\mathrm{C}>3\right)$ & 9 \\
\hline $\mathrm{C}_{3} \mathrm{H}_{6}$ (propene) & 6 \\
\hline \multicolumn{2}{|l|}{ Biogenic } \\
\hline $\mathrm{C}_{10} \mathrm{H}_{16}$ (lumped monoterpenes as $\alpha$-pinene) & 89 \\
\hline ISOP $\left(\mathrm{C}_{5} \mathrm{H}_{8}:\right.$ isoprene $)$ & 462 \\
\hline
\end{tabular}

* A multiplication factor of 1.4 (Griffin et al., 1999) was used to convert primary organic carbon (POC) to primary organic aerosol (POA) mass.

Northern Hemisphere (Fig. 3) where the base-case SOA concentrations are generally negligible. Replacing the default SOA parameters with the $2 \mathrm{p}-\mathrm{VBS}$ parameters increased predicted SOA mass concentrations by $0.1-0.2 \mu \mathrm{g} \mathrm{m}^{-3}$ in the eastern USA, $0.2-0.6 \mu \mathrm{g} \mathrm{m}^{-3}$ in Europe, $0.3-0.9 \mu \mathrm{g} \mathrm{m}^{-3}$ in eastern China, and $0.2-0.4 \mu \mathrm{g} \mathrm{m}^{-3}$ in the Amazon and Southeast Asia throughout the year. Figure 4 shows the fractional change in monthly average SOA relative to the base case as predicted by MZ4-C2. SOA increased over some areas in the eastern USA, western Europe, South and Southeast Asia, and China by as much as $\sim 2-4$ times $(\sim 200-400 \%)$; in MZ4$\mathrm{C} 2$, predicted SOA concentrations were $\sim 0.1-0.2 \mu \mathrm{g} \mathrm{m}^{-3}$ throughout the year, except for the month of September, which showed higher increases (up to $\sim 600 \%$ ) in some parts of the USA, China, and South and Southeast Asia. The highest increase of SOA $(\sim 16-28$ times the base case) was predicted in northwestern Australia during the months of September and December. In these regions, greater increases in SOA were predicted due to the contribution of isoprene in September and December (which follows the pattern of isoprene emissions at these times of the year in these regions). Given the absence of isoprene as an SOA precursor in the base case, the corresponding base-case concentrations of SOA in these regions were usually low $\sim 0.01-0.04 \mu \mathrm{g} \mathrm{m}^{-3}$. MZ4-C2 predicted 400-600\% increases in some hotspots in the Amazonian regions in South America throughout the year. Similar increases were also seen in middle and southern parts of Africa during the months of March, September and December. Again, these patterns of increased SOA followed the patterns of isoprene emissions during corresponding months. The difference in plots between the MZ4-C2 and base-case simulations (not shown) indicated significant increases in SOA concentrations $\left(>1.0 \mu \mathrm{g} \mathrm{m}^{-3}\right)$ in the equatorial Africa, Amazonian region, eastern China, and Southeast Asia, due to high emissions of biogenic precursors, namely isoprene, in these regions.
Table 3 contains regionally averaged annual SOA concentrations at the surface with $\pm 1 \sigma$, which represents both spatial and temporal variations, for several geographic areas around the world for all three model simulations. The area coordinates were adopted from Emmons et al. (2010). The regional averages were calculated based on SOA concentrations in all grid cells over land within the specified coordinates using the global land-mask field. The base-case annual average SOA concentrations were generally high in regions with higher emissions from biogenic sources, in this case, monoterpenes only (e.g., Fig. 1). With MZ4-C1 (SOA parameter updates) the concentration of SOA increased from the base case between $\sim 8$ and $108 \%$. It is interesting to note that the changes were usually greater for areas where SOA was low, but heavily dominated by anthropogenic emissions. For example, USA, Europe, North Asia and Southeast Asia showed relatively higher SOA mass increases, $\sim 16$ $108 \%$ (over the base case). In comparison, SOA mass increases in regions in South America, Indonesia, Africa, and Australia were generally lower, $\sim 8-16 \%$. (These changes due to parameter updates also are reflected in Fig. 3.) For the MZ4-C2 simulations (SOA parameter updates and additional SOA precursors) regionally averaged annual SOA increased from the base case by as much as $~ 90-600 \%$ (or $\sim 0.9-6$ times). The increase was attributed mostly to the consideration of isoprene as an SOA precursor, which accounted for $\sim 99 \%$ of the increased global SOA production in MZ4-C2, compared to the two anthropogenic precursors, namely propene $\left(\mathrm{C}_{3} \mathrm{H}_{6}\right)$ and lumped big alkenes (BIGENE), which accounted for the remaining $\sim 1 \%$. The standard deviation $( \pm 1 \sigma)$ shows the regional variability in SOA prediction. Higher $\pm 1 \sigma$ represents higher variability within the specified regions and vice versa. The source of variability in predicted SOA in this study can be attributed to the variability of regional biogenic emissions (see Fig. 2). 

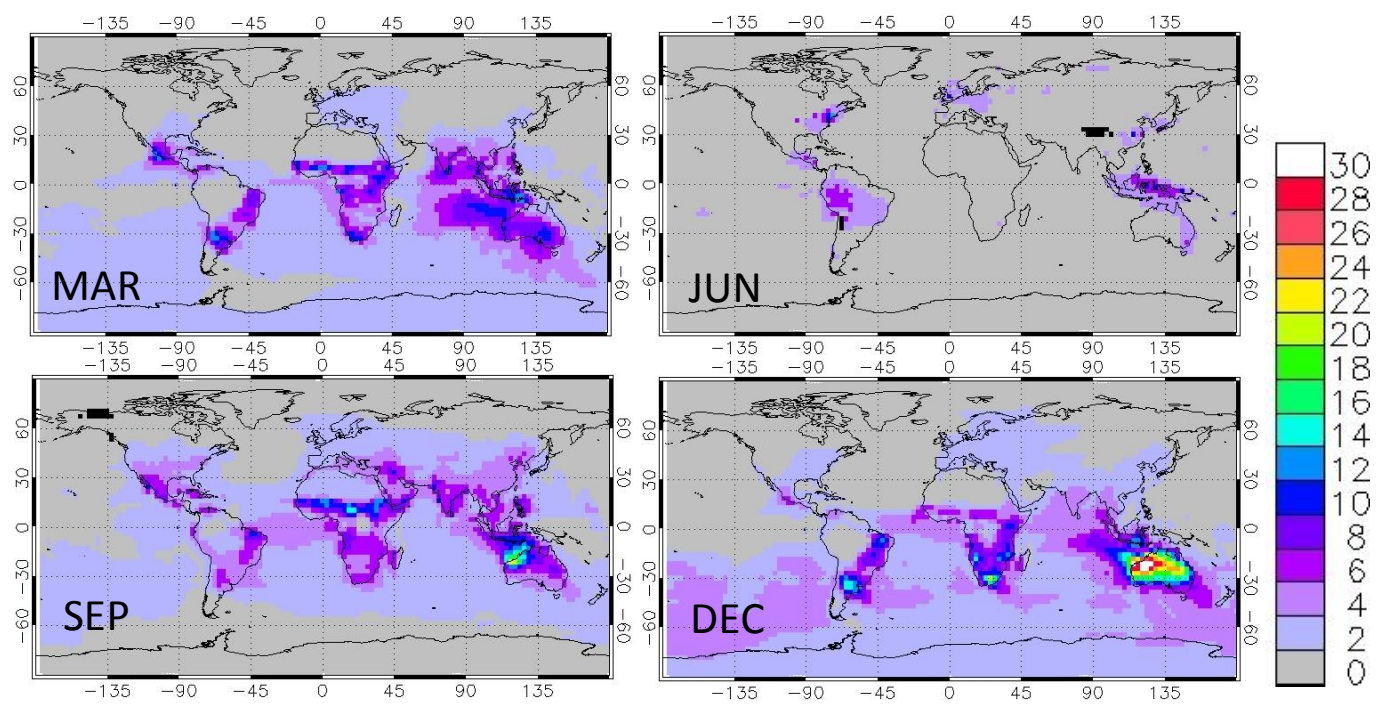

Fig. 4. Fractional change in simulated surface SOA concentrations due to $2 p$ parameter updates and consideration of additional SOA precursors (MZ4-C2) relative to the base case.

Table 3. Regionally averaged annual SOA concentrations at the surface for the year 2006.

\begin{tabular}{lccc}
\hline \multirow{2}{*}{ Region } & \multicolumn{3}{c}{ Annual average $( \pm 1 \sigma) \mathrm{SOA}\left(\mu \mathrm{g} \mathrm{m}{ }^{-3}\right)$ at the surface } \\
\cline { 2 - 4 } & Base-case & MZ4-C1 & MZ4-C2 \\
\hline Canada $\left(50-70^{\circ} \mathrm{N}, 125-60^{\circ} \mathrm{W}\right)$ & $0.07 \pm 0.03$ & $0.08 \pm 0.04$ & $0.14 \pm 0.09$ \\
USA $\left(25-50^{\circ} \mathrm{N}, 125-60^{\circ} \mathrm{W}\right)$ & $0.09 \pm 0.05$ & $0.14 \pm 0.10$ & $0.37 \pm 0.27$ \\
Europe $\left(35-70^{\circ} \mathrm{N}, 10^{\circ} \mathrm{W}-45^{\circ} \mathrm{E}\right)$ & $0.12 \pm 0.07$ & $0.25 \pm 0.17$ & $0.47 \pm 0.29$ \\
North Asia $\left(45-70^{\circ} \mathrm{N}, 60-150^{\circ} \mathrm{E}\right)$ & $0.06 \pm 0.05$ & $0.08 \pm 0.08$ & $0.17 \pm 0.18$ \\
Southeast Asia $\left(10-45^{\circ} \mathrm{N}, 60-125^{\circ} \mathrm{E}\right)$ & $0.10 \pm 0.11$ & $0.18 \pm 0.18$ & $0.56 \pm 0.66$ \\
Indonesia $\left(10^{\circ} \mathrm{S}-10^{\circ} \mathrm{N}, 90-150^{\circ} \mathrm{E}\right)$ & $0.31 \pm 0.38$ & $0.36 \pm 0.44$ & $1.57 \pm 1.88$ \\
North Africa $\left(\mathrm{Eq}-30^{\circ} \mathrm{N}, 20^{\circ} \mathrm{W}-55^{\circ} \mathrm{E}\right)$ & $0.07 \pm 0.11$ & $0.09 \pm 0.12$ & $0.36 \pm 0.50$ \\
South Africa $\left(40^{\circ} \mathrm{S}-\mathrm{Eq}, 0-55^{\circ} \mathrm{E}\right)$ & $0.08 \pm 0.09$ & $0.09 \pm 0.11$ & $0.45 \pm 0.37$ \\
South America $\left(30^{\circ} \mathrm{S}-\mathrm{Eq}, 90-30^{\circ} \mathrm{W}\right)$ & $0.36 \pm 0.50$ & $0.39 \pm 0.52$ & $1.00 \pm 1.04$ \\
Australia $\left(45-10^{\circ} \mathrm{S}, 110-160^{\circ} \mathrm{E}\right)$ & $0.06 \pm 0.07$ & $0.07 \pm 0.08$ & $0.52 \pm 0.34$ \\
\hline
\end{tabular}

\subsubsection{Vertical profiles}

Several past and recent studies found that global chemical transport models poorly represent observed concentrations of SOA in the vertical direction (see for example, Heald et al., 2005, 2011; and Lin et al., 2012). Efforts were made in the current study to examine how changes in SOA at the surface, driven by updates to the SOA module, translated to the other vertical layers. MOZART- 4 has 28 vertical layers extending up to $\sim 2.7 \mathrm{hPa}(\sim 30 \mathrm{~km})$ above ground. Figure 5 shows vertical profiles of regionally averaged annual SOA concentrations for four regions: USA, Indonesia, South America and Japan. The figure shows that updating the SOA parameters (MZ4-C1) had little effect on the vertical profiles compared to the base case; whereas, treating the additional SOA precursors (MZ4-C2), namely isoprene, had a significant effect on vertical profiles. The reason for the increase in SOA aloft is likely two-fold. First, as noted by Henze and Seinfeld (2006), is the magnitude of isoprene emissions; and second, is the relatively high yield/low volatility of isoprene SOA product 1 , as determined by the fitted $\alpha$ and $K_{\mathrm{p}}$ values shown in Table 1. MZ4-C2-predicted SOA increased by $\sim 160, \sim 300$, $\sim 170$ and $\sim 150 \%$ in the free troposphere (between 801.40 $435.70 \mathrm{hPa}, \sim 2-6 \mathrm{~km}$ ) for USA, Indonesia, Japan, and South America from the base-case annual average of 0.03, 0.08, 0.03 , and $0.12 \mu \mathrm{g} \mathrm{m}^{-3}$, respectively.

\subsubsection{Global budgets}

Estimated global production, deposition, lifetime and atmospheric burden of SOA are presented in Table 4 for all three model simulations. The net production of SOA is assumed to be equal to the net deposition flux, mostly dry and wet deposition, in all simulations. SOA production of $5.8 \mathrm{Tg} \mathrm{yr}^{-1}$ was estimated in the base case, while 6.6 and $19.1 \mathrm{Tg} \mathrm{yr}^{-1}$ were 
Table 4. Global SOA budget estimates.

\begin{tabular}{lcrrrr}
\hline \multirow{2}{*}{ Model versions } & \multicolumn{2}{l}{ Removal $\left(\mathrm{Tg} \mathrm{yr}^{-1}\right)$} & Production $\left(\mathrm{Tg} \mathrm{yr}^{-1}\right)$ & Lifetime (days) & Burden $(\mathrm{Tg})$ \\
\cline { 2 - 3 } & \multicolumn{1}{c}{ Dry } & Wet & & & \\
\hline Base case & 1.1 & 4.7 & 6.8 & 13.6 & 0.22 \\
Updated-MZ4-C1 & 1.4 & 5.2 & 19.6 & 13.1 & 0.24 \\
Updated-MZ4-C2 & 4.7 & 14.4 & 11.2 & 0.59 \\
\hline
\end{tabular}
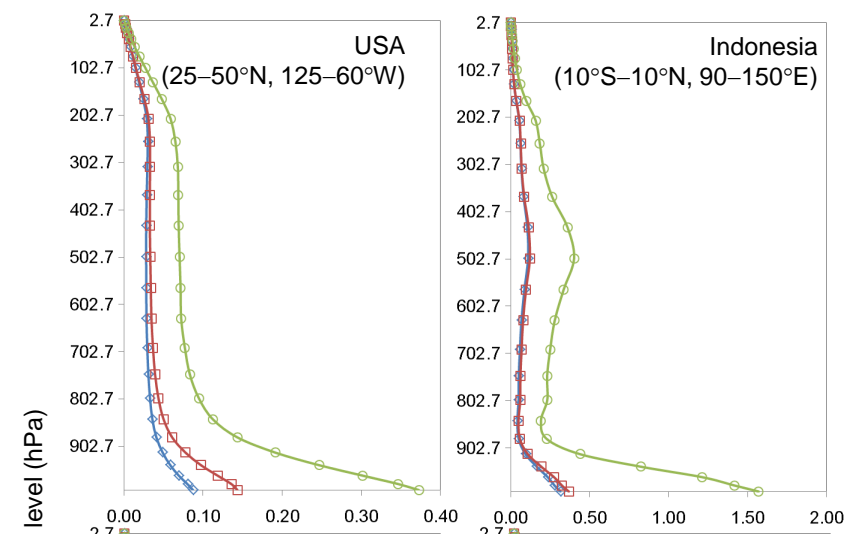

产

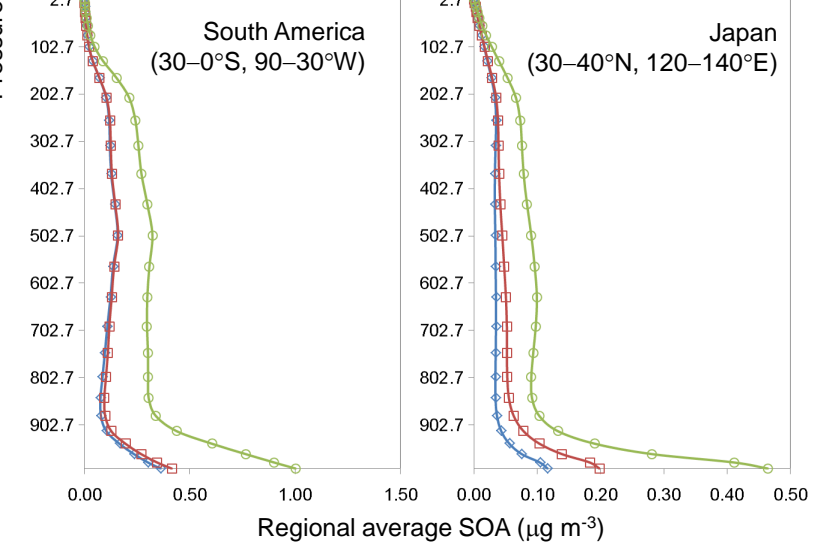

Fig. 5. Vertical distributions of regionally averaged annual SOA concentrations $\left(\mu \mathrm{g} \mathrm{m}^{-3}\right)$. Simulated SOA concentrations for the base case are represented by open diamonds (blue); open squares (red) represent updated version, MZ4-C1 (updated $2 \mathrm{p}$ parameters), and open circles (green) represent updated version, MZ4-C2 (updated $2 \mathrm{p}$ parameters and additional parent VOCs).

estimated in MZ4-C1 and MZ4-C2, respectively. Updates to the SOA parameters and inclusion of additional precursors clearly enhanced SOA production, which also increased atmospheric burdens by 8 and $168 \%$, respectively, from the base case. Among the three newly treated parent VOC species, isoprene contributed $\sim 99 \%$ to additional production of atmospheric SOA (through $\mathrm{OH}$ oxidation) and for $\sim 65 \%$ of total atmospheric SOA production. Comparable modeling studies reported that isoprene alone can generate up to $15-75 \%$ of atmospheric SOA (see for example, Heald et al., 2006; Henze and Seinfeld, 2006; Hoyle et al., 2007; Liao et al., 2007; and Tsigaridis and Kanakidou, 2007). The SOA lifetime estimated from the base-case simulation was 13.6 days; estimated SOA lifetime for MZ4-C1 and MZ4-C2 was 13.1 and 11.2 days, respectively. The shorter calculated lifetime for MZ4-C2 (-18\% relative to the base case) was likely due to the inclusion of isoprene as an SOA precursor. The atmospheric lifetimes of biogenic precursors $(\sim \mathrm{h})$ are generally shorter than anthropogenic precursors ( $\sim$ days) (Farina et al., 2010); thus, anthropogenic precursors are more likely to be transported to higher altitudes prior to the formation of SOA, where dry and wet deposition are less efficient (Lin et al., 2012). In MZ4-C2, much of the enhanced SOA formation (due to isoprene) was within the first few layers (within $\sim 500 \mathrm{~m}$ above ground, see Fig. 4 ) where dry and wet depositions are very effective. Two additional simulations were carried out to illustrate this lifetime effect. With anthropogenic precursors only in the SOA module, the predicted SOA lifetime was 17.6 days, compared to the predicted SOA lifetime of 11.2 days for the biogenic only case. The biogenic only simulation was essentially equivalent to MZ4-C2, with isoprene being the largest contributor to SOA production. The predicted SOA mass concentrations between the anthropogenic only simulation (lifetime $\sim 17.6$ days), the base case (lifetime $\sim 13.6$ days) and MZ4-C1 (lifetime $\sim 13.1$ days) were similar in magnitude (as compared with MZ4-C2); however, the presence of the biogenic (specifically monoterpenes) precursors in the base-case and MZ4-C1 simulations resulted in greater SOA formation at the surface, and thus an increase in deposition and decrease in SOA lifetime.

\subsection{Model evaluation}

Predicted SOA and total organic aerosol (OA) mass concentrations and aerosol optical depth (AOD) were compared with observations and previous modeling studies. For modelmodel comparisons, SOA abundance and budget estimates are from models that employed a $2 \mathrm{p}$ SOA model approach on a relatively coarse grid (in the order of degrees), unless stated otherwise. For the purpose of measurement-model and model-model comparisons, where necessary, a conversion factor of 1.4 (suggested by Griffin et al., 1999 and Russell et al., 2003) was used to convert between organic aerosol mass $(\mathrm{OM})$ and organic carbon mass (OC). Because of the variability in measured and suggested OM: OC values (e.g., 


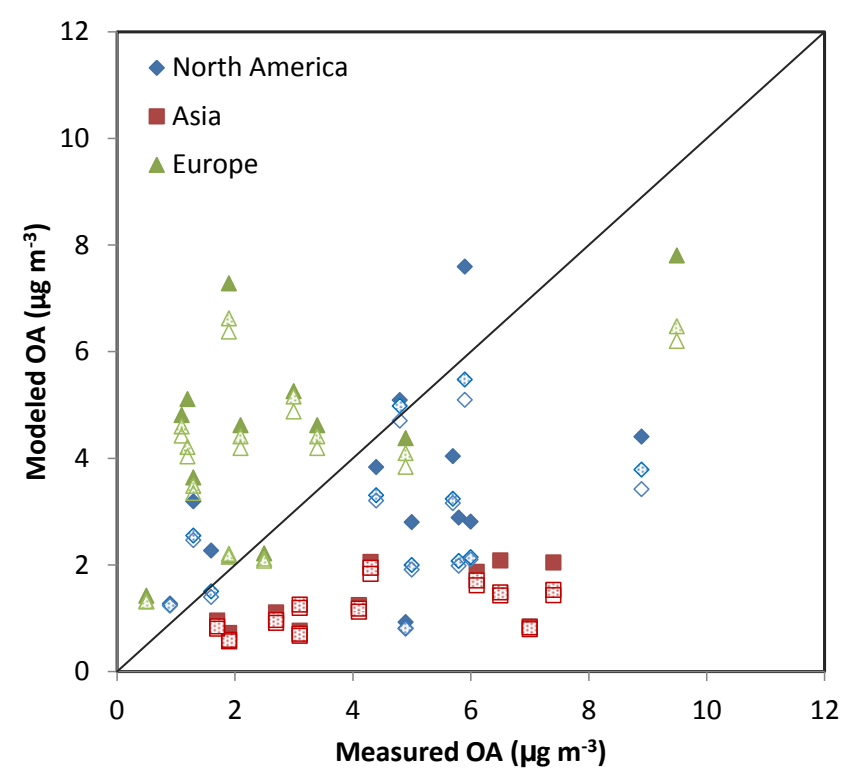

Fig. 6. Modeled vs. measured OA mass concentrations at several locations in North America, Europe and Asia. The solid fill represents MZ4-C2, patterned fill represents MZ4-C1, and no fill represents MZ4 base-case simulations. Measured data were adapted from Zhang et al. (2007).

from 1.3; Liousse et al., 1996 to 2.2; and Zhang et al., 2005) the choice of the OM : OC value is one source of uncertainty in model evaluation. The value of 1.4 used here is on the lower end of the global mean values and thus may bias results toward under-prediction if POA is converted from primary organic carbon (POC) and/or over-prediction if SOA is converted to secondary organic carbon (SOC) in the analysis. In the current version of MOZART4, SOA yields are calculated only for high $\mathrm{NO}_{\mathrm{X}}$ pathways, which may bias SOA concentrations, particularly in regions under low $\mathrm{NO}_{\mathrm{X}}$ conditions. This could be another source of uncertainty when comparing modeled concentrations with observations. However, the discussion of modeled concentrations in Sect. 3.1 indicated that because of the overwhelming contribution of isoprene (for which high and low $\mathrm{NO}_{\mathrm{X}}$ parameters currently do not exist) to SOA on the global scale, the bias from high $\mathrm{NO}_{\mathrm{X}}$ parameters are less likely to be significant in the current analysis.

\subsubsection{Surface SOA}

Surface measurement data of OA at several locations in North America, Europe and Asia were obtained from Zhang et al. (2007). The list of the dataset names, categories and geographic locations of sampling sites, and the duration of each measurement campaign can be found in Zhang et al. (2007). Corresponding model results from the MZ4-C2, MZ4-C1, and the base-case simulations were then compared with observations. Figure 6 shows a scatter plot of modeled vs. measured OA concentrations. The solid, patterned, and open symbols represent modeled concentrations for MZ4$\mathrm{C} 2$, MZ4-C1, and base-case MZ4 simulations, respectively. The figure shows that even with the updated $2 p$ parameters and added precursors, MOZART-4 (MZ4-C2) underestimated (NMB (normalized mean bias): $-70 \%$ ) measured OA concentrations at all remote and urban sites in Asia (solid squares), and the model has showed slight improvement over the base-case simulation (NMB: $-76 \%$ ). The severe underestimation at sites in Asia is perhaps due to the fact that most of the measurements were taken at rural sites that were likely impacted by pollutants transported from nearby regions over a short period of time, but the model perhaps did not capture those episodic pollution events in the simulation. The updated model over-estimated measurements at most urban sites in Europe (solid and patterned triangles, NMB: 63 and 49\%), even the base-case simulation (open triangles, NMB: $43 \%$ ) showed over-estimation in those sites. The over-estimation of total OA could be attributed to the fact that the model grids where the measurements took place perhaps did not have representative conditions for emissions and meteorology. The OM:OC ratio of 1.4 applied in the analysis might not be appropriate for Europe. Measured OA concentrations at several sites in North America (solid diamonds), however, were relatively better reproduced by the MZ4-C2 (NMB: - 27\%) simulation compared to the MZ4C1 (NMB: $-41 \%$ ) and base-case (NMB: $-44 \%$ ) simulations in the current study. Therefore, only the MZ4-C2 results will be further compared with observations and previously published modeling results.

MZ4-C2 predicted increased SOA mass concentrations at the surface in North America (particularly in the eastern USA) and Europe during the summer months of June, July and August, when biogenic emissions are at their peak. Using GEOS-Chem, Liao et al. (2007) predicted climatological average (2001-2003) summertime SOA concentrations of $\sim 0.5-2$ and $\sim 0.5-1 \mu \mathrm{g} \mathrm{m}^{-3}$ from isoprene and monoterpene precursors over the southeastern and northeastern USA, respectively. In this study, predicted summertime SOA concentrations were $\sim 0.9-1.3$ and $\sim 1.3-1.4 \mu \mathrm{g} \mathrm{m}^{-3}$ over the northeastern and southeastern USA, respectively. Farina et al. (2010) reported that the GISS II GCM predicted SOA reasonably well over Europe. Estimated monthly average OM concentrations were between 8.5 and $8.9 \mu \mathrm{g} \mathrm{m}^{-3}$ while the observed monthly average was $6.9 \mu \mathrm{g} \mathrm{m}^{-3}$ for the period 2002-2003. In the present study, the modeled monthly average $\mathrm{OM}$ for the same region (Europe) was $\sim 5.0 \mu \mathrm{g} \mathrm{m}^{-3}$ for the year 2006.

MZ4-C2 predicted significant increases in SOA in several regions in Asia, including areas within Southeast Asia and eastern parts of China. Although there are no continuous measurement data available for Southeast Asia, Zhang et al. (2012) has presented SOC measurement data for several locations within China collected over a two-year period (2006-2007). Figure 7 shows a comparison between modeled vs. measured SOC at 14 sites in China. The list of 


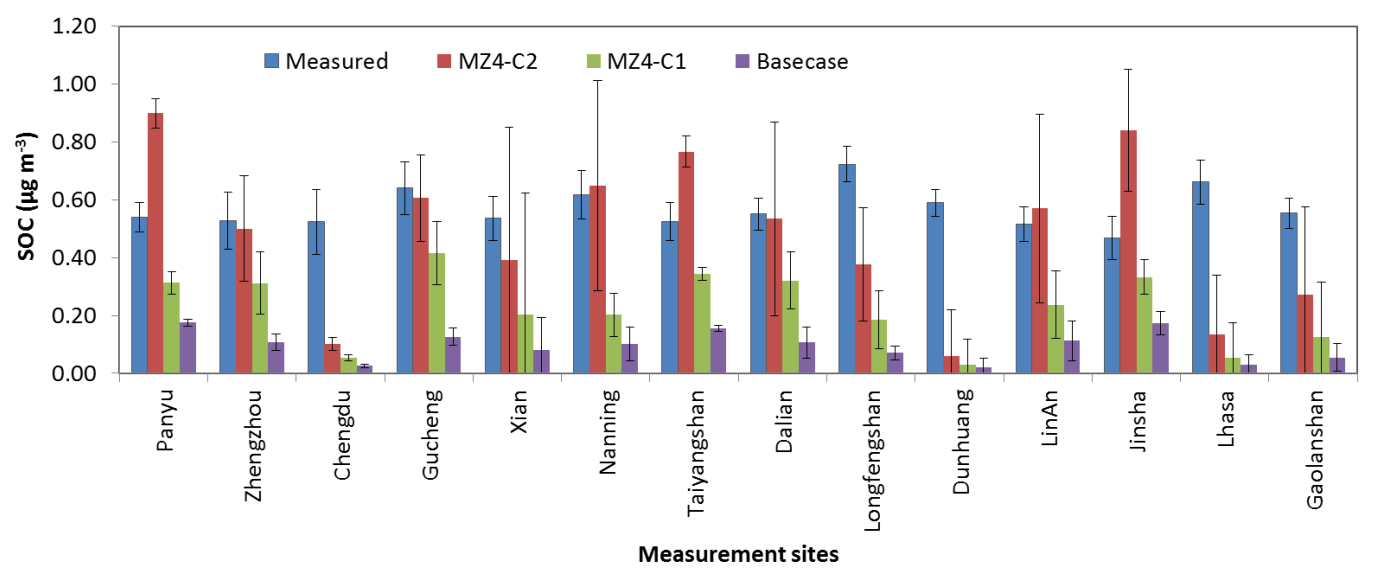

Fig. 7. Measured vs. modeled comparison of SOC at various measurement sites in China. Measured data were obtained from Zhang et al. (2012).

sites, categories and their geographic locations can be found in Zhang et al. (2012). The error bars in the plot represent $\pm 1 \sigma$ of annual average SOC concentrations. The comparison emphasizes that the MZ4-C2 produced SOA mass concentrations relatively well at 8 out of 14 sites compared to MZ4-C1 and base case, where $\pm 1 \sigma$ between measured and modeled averages overlap. Robinson et al. (2011) reported a measured $\mathrm{OM}$ concentration of $0.74 \mu \mathrm{g} \mathrm{m}^{-3}$ at the surface in the Malaysian Borneo $\left(4.981^{\circ} \mathrm{N}, 117.844^{\circ} \mathrm{E}\right)$ during the oxidant and particulate photochemical processes above a Southeast Asian rainforest (OP3)/Aerosol Coupling in the Earth's System (ACES) project (June-July 2008). For these two months in summer, MZ4-C2 predicted a monthly average $\mathrm{OM}$ of $\sim 2.3 \mu \mathrm{g} \mathrm{m}^{-3}$ of which $\sim 58 \%$ was attributable to SOA derived from isoprene oxidation. This apparent overprediction may be explained by an erroneously high isoprene SOA yield or unrepresentative $2 \mathrm{p}$ parameters (for the modeled ambient conditions), the assumed value of the OM: OC ratio and/or the over-estimation of modeled emission rates utilized in the current study. In a recent modeling study, Jiang et al. (2012) estimated annual average SOA concentrations of $\sim 2.78$ and $\sim 2.92 \mu \mathrm{g} \mathrm{m}^{-3}$ for areas within southern China $\left(22-26^{\circ} \mathrm{N}, 100-115^{\circ} \mathrm{E}\right)$ and central China (25$\left.35^{\circ} \mathrm{N}, 103-120^{\circ} \mathrm{E}\right)$, respectively, for the year 2006 using a regional-scale model, WRF-Chem (Weather Research and Forecasting-Chemistry). MZ4-C2 predicted annual average SOA concentrations of $1.11 \pm 0.59$ and $0.88 \pm 0.42 \mu \mathrm{g} \mathrm{m}^{-3}$ for southern and central China, respectively. The SOC:OC ratio predicted by MZ4-C2 was $\sim 17 \%$ compared to $\sim 16 \%$ reported by Jiang et al. (2012) in northern China, while observed SOC: OC ratios of $\sim 26-59 \%$ have been reported for the Beijing area (Dan et al., 2004; Chan et al., 2005; Duan et al., 2005; Lin et al., 2009). Thus, the updated version of MOZART, MZ4-C2, generally predicted SOA concentrations comparable to other similar modeling studies for regions in China, but over-predicted measured summertime monthly average concentrations in the forested region in Southeast Asia.

Recall that MZ4-C2 predicted generally high SOA concentrations in and around the Amazonian regions in South America. Like regions in Asia, OA measurement data in the Amazonian region are also limited and sporadic. Gilardoni et al. (2011) reported a measured OM concentration of $1.70 \mathrm{\mu g} \mathrm{m}^{-3}$ at the surface in the Amazonian basin during the wet season (February-June); Chen et al. (2009) reported concentrations of submicron $(<1 \mu \mathrm{m})$ OM during the FebruaryMarch period of $0.7 \mu \mathrm{g} \mathrm{m}^{-3}$. An average OM concentration of $\sim 2.15 \mu \mathrm{g} \mathrm{m}^{-3}$ was predicted in the current study for the Amazonian region during the wet season. Another modeling study by Lin et al. (2012) predicted an average $\mathrm{OM}$ of $\sim 3.5 \mu \mathrm{g} \mathrm{m}^{-3}$ for the same region and season. The modeled concentrations from the current study and Lin et al. (2012) appear to be over-estimating OM in this region. Such over-estimations could be due to an over-estimation of the isoprene SOA yield (for the ambient conditions modeled) and/or an over-estimation of the emissions (of SOA precursors and/or POA) in the region. This discrepancy may also be attributed to different meteorology being used in simulations as compared with the meteorology during the measurement periods.

\subsubsection{Vertical profiles}

Several field campaigns have been carried out to understand the abundance of OC, as well as SOA, specifically in the vertical direction. In such campaigns, measurements are carried out along flight paths at different altitudes within a specific region of interest. Two of such early major field campaigns were ACE-Asia at the Fukue Island off the coast of Japan in April-May 2001, and ITCT-2K4 over NE North America in July-August of 2004. Data from these campaigns are often utilized to validate model performance in the vertical 
direction (see for example, Heald et al., 2005, 2006; and Lin et al., 2012). Recently, Heald et al. (2011) presented a comprehensive analysis of OA vertical profiles from 17 field campaigns from 2001-2009 (including the two mentioned above) in order to validate model performance on a global scale. In this study, comparisons of modeled vertical profiles were limited to the early field campaigns over the northwest Pacific (ACE-Asia) and the northeast of North America (ITCT2K4).

Heald et al. (2005) reported that GEOS-Chem underpredicted OC, of which SOA is a dominant component, by as much as 10-100 times during the ACE-Asia (2001) study near the coast of Japan $\left(23-43^{\circ} \mathrm{N}, 120-145^{\circ} \mathrm{E}\right)$. MZ4-C2 in the current study predicted a seasonal (April-May) OC aerosol mass of $0.58 \pm 0.24 \mu \mathrm{g} \mathrm{C} \mathrm{m}^{-3}$ in the free troposphere (FT) averaged over all the grid cells within the area boundary at model resolution, of which $\sim 16 \%$ was attributed to SOA; the observed seasonal average OC mass along the fight paths was $3.3 \pm 2.8 \mu \mathrm{g} \mathrm{C} \mathrm{m}^{-3}$. The predicted OC mass concentration in the current study showed a significant improvement from the reported maximum modeled value of $0.30 \pm 0.3 \mu \mathrm{g} \mathrm{C} \mathrm{m}^{-3}$ by Heald et al. (2005) averaged over the grid cells along the flight paths. It is worth noting that Heald et al. (2005) treated monoterpenes as the only biogenic VOC precursor, whereas MZ4-C2 includes both monoterpenes and isoprene. The model prediction in the current study is comparable with the FT average modeled OC aerosol mass of $\sim 0.7 \mu \mathrm{g} \mathrm{C} \mathrm{m}^{-3}$ (STP, standard temperature and pressure) reported by Lin et al. (2012) for the ACE-Asia field campaign; similarly to this work, Lin et al. (2012) considered isoprene and monoterpenes as major biogenic precursors.

During the ITCT-2K4 campaign $\left(25-55^{\circ} \mathrm{N}, 270-310^{\circ} \mathrm{E}\right)$ over summer months July-August, aircraft measurements included those within a large plume that originated from boreal forest fires in Alaska and Canada. Chemical transport models often miss such plumes resulting in significant underprediction of OM. Heald et al. (2006) reported observed water soluble organic carbon (WSOC) concentrations of $0.9 \pm 0.9 \mu \mathrm{g} \mathrm{C} \mathrm{m}^{-3}$ in the FT averaged along the flight paths outside of the boreal forest fire plume, and a corresponding modeled WSOC concentration of $0.7 \pm 0.6 \mu \mathrm{C} \mathrm{m}^{-3}$ averaged from only grid cells along the flight paths at model resolution. In the current study, MZ4-C2 predicted seasonal WSOC aerosol mass of $0.36 \pm 0.15 \mu \mathrm{g} \mathrm{C} \mathrm{m}{ }^{-3}$, of which $21 \%$ was attributable to SOA, in the FT averaged from all grid cells within the region boundary specified. Both the current study and Heald et al. (2006) included monoterpenes and isoprene as major biogenic precursors with similar emission strengths; the apparent difference in model prediction may have been due to differences in how the average results are calculated.

\subsubsection{Global budgets}

There is significant uncertainty in global SOA budget estimates. A wide range of SOA production rates, measurement and model based, can be found in the literature. For example, Goldstein and Galbally (2007) estimated SOA production of 510-910 $\mathrm{Tg} \mathrm{C} \mathrm{yr}^{-1}$ based on a top-down VOC mass balance approach. Global model estimates of SOA production based on bottom-up approaches typically span a lower range, from $6.74 \mathrm{Tg} \mathrm{yr}^{-1}$ (Goto et al., 2008) to $96 \mathrm{Tg} \mathrm{yr}^{-1}$ (Guillaume et al., 2007). The differences in SOA production and atmospheric burden among these model estimates predominantly come from differences in source emissions, choice of SOA parameters, and treatment of parent VOCs in SOA models. Nevertheless, inter-comparisons between models provide useful information for testing and validating model performance. Thus SOA production, lifetime and corresponding atmospheric burden estimates from the current study were compared with estimates from other global chemical transport models.

Estimated global SOA production of $19.1 \mathrm{Tg} \mathrm{yr}^{-1}$ with a lifetime of 11.2 days and corresponding atmospheric burden of $0.59 \mathrm{Tg}$ were estimated for MZ4-C2, which falls well within the reported range of model estimates cited above. Recently O'Donnell et al. (2011) estimated global SOA production of $26.6 \mathrm{Tg} \mathrm{yr}^{-1}$ with a lifetime of 11.4 days and corresponding global burden of $0.83 \mathrm{Tg}$, which are in close agreement with the estimates in this work. O'Donnell et al. (2011) utilized the ECHAM5-HAM global model, which, like MOZART-4, also assumes the net deposition of SOA equals the net production of SOA in the atmosphere provided that the pre-existing organic mass $\left(M_{\mathrm{o}}\right)$ is also subject to removal processes. Differences in dry and wet deposition schemes and the additional sink process through sedimentation might have resulted in higher production of $\mathrm{SOA}$, as the underlying assumption was that the production of SOA equals to the total removals in O'Donnell et al. (2011) compared to the current study. An earlier study by Henze et al. (2008) estimated global SOA production of $30.3 \mathrm{Tg} \mathrm{yr}^{-1}$ using the GEOS-Chem model. The higher global SOA production in Henze et al. (2008) can be attributed to the inclusion of $\mathrm{NO}_{\mathrm{X}}$ dependent $\mathrm{SOA}$ formation pathways for anthropogenic precursors (not currently an option in the MOZART-4 SOA module), and treatment of additional SOA precursors (benzene, alcohols and sesquiterpenes). For the anthropogenic precursors, SOA formation is favored under low $\mathrm{NO}_{\mathrm{X}}$ conditions relative to high $\mathrm{NO}_{\mathrm{X}}$ conditions. Hoyle et al. (2007) estimated global SOA production of approximately $55 \mathrm{Tg} \mathrm{yr}^{-1}$, of which $15 \mathrm{Tg} \mathrm{yr}^{-1}$ was formed by the oxidation products of isoprene. Tsigaridis and Kanakidou (2007) estimated a global annual mean SOA production of $16.6 \mathrm{Tg} \mathrm{yr}^{-1}$ from biogenic VOCs, which was within their earlier (2003) estimated range of SOA production rate from biogenic sources of 2.5 to $44.5 \mathrm{Tg} \mathrm{yr}^{-1}$. All of these model estimates are significantly lower than 

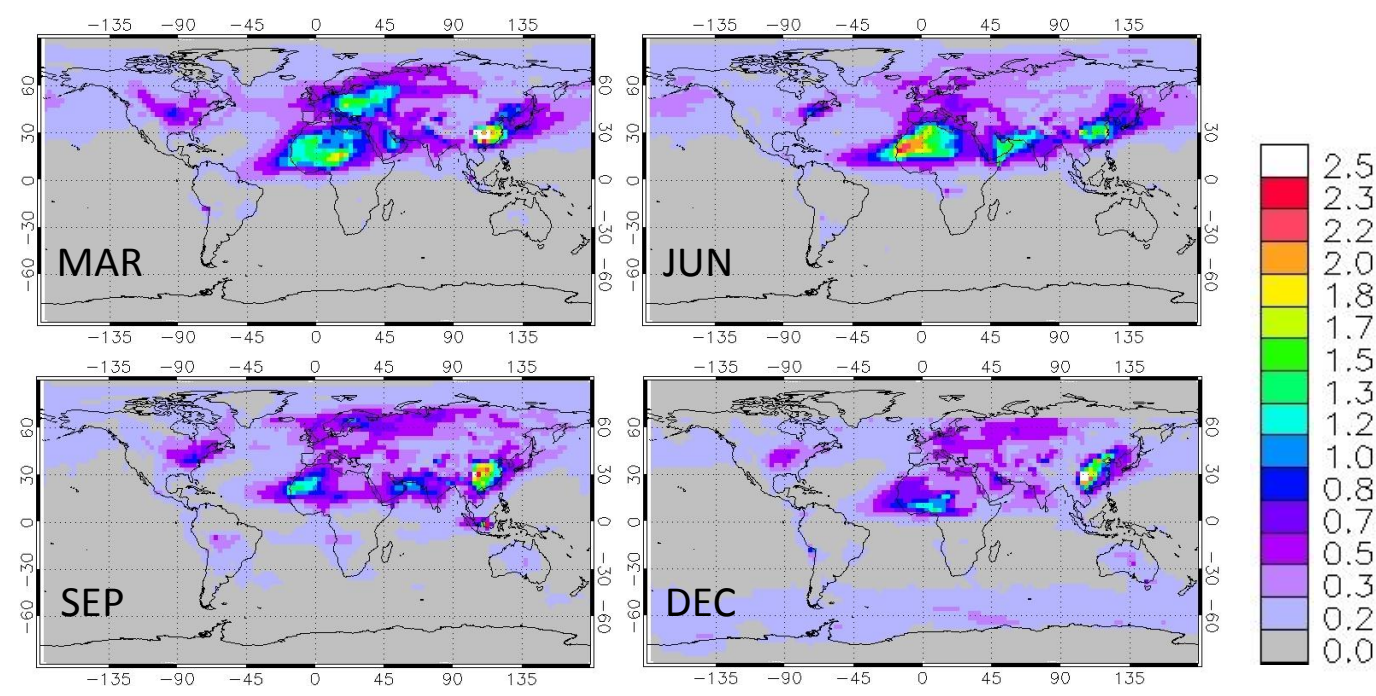

Fig. 8. Global distributions of monthly average total AOD for the base-case MOZART-4 simulations.

the observationally constrained top-down estimates (50$380 \mathrm{Tg} \mathrm{yr}^{-1}$ ) of Spracklen et al. (2011).

\subsection{Aerosol optical depth}

In MOZART-4, the AOD is calculated only when the photolysis rates are calculated (zenith angle, SZA is less than $90^{\circ}$ ), so the monthly average total AOD was scaled by the fraction of daylight hours per day estimated in the model. Total AOD reflects contributions from aerosols originating from primary and secondary organics, sea salt, sulfate, nitrate, and dust. The FTUV module in MOZART-4 generates 17 wavelength bins for each of which optical properties of those aerosol types are utilized. The optical and physical property data for each of those types of aerosol were obtained mostly from OPAC dataset by Hess et al., 1998. Except dust, other aerosol types including sulfate, nitrate, organic carbon, black carbon, SOA and sea salt are treated for water uptake in the AOD calculation in the model. In the absence of adequate data, SOA is treated similarly to OC in AOD calculations.

Figure 8 shows the modeled spatial distribution of total AOD for the base-case MOZART-4 simulations. The monthly averaged total AOD presented here includes contributions from primary and secondary $\mathrm{OC}, \mathrm{BC}$, dust, sea salt, and sulfate and nitrate particles. As shown in Fig. 8, AOD is generally higher for the Northern Hemisphere than the Southern Hemisphere, supporting that primary anthropogenic particulate emissions (e.g., BC) and dust are the largest contributors to modeled AOD; this is in contrast to the significant contribution of biogenic emissions to total particulate loadings through SOA formation. High AOD $(>\sim 2.0)$ over Northern Africa reflects large contributions $(\sim 80 \%)$ from dust particles, and over southeastern China from anthropogenic sources $(>\sim 90 \%)$ including $\mathrm{BC}$, sulfate, nitrate and OC. However, the contribution of OC to total AOD is generally $<\sim 20 \%$ in the modeled regions (Table 5).

The fractional increase of total AOD in the updated model simulation (MZ4-C2) from the base case was calculated. The increase in AOD was in the range of $\sim 1-7 \%$ in areas where SOA production also increased due to treatment of additional SOA precursor VOCs. To illustrate further that anthropogenic aerosols dominate AOD, regionally averaged annual AOD was calculated for several regions including over major oceans of the world. Table 5 contains regionally averaged base-case annual total AOD, contributions from POA and SOA, and change in total AOD attributed to additional SOA formed in the MZ4-C2 simulations. The table contains total AOD analysis for the regions for which SOA was also averaged annually (Table 3). Additionally, annual total AOD results over oceans are presented. Note that the AOD over oceans was calculated using ocean only grid cells within the boundary coordinates. Generally, AOD was much higher over land compared to over oceans because sources are located over land. The base-case model predicted the highest annual average total AOD of 0.73 over North Africa, of which $\sim 80 \%$ is attributed to dust; only $3 \%$ is attributed to POA and SOA. MZ4-C2 predicted POA and SOA contributed $\sim 3-21 \%$ to total AOD over the regions considered in the current study. Regionally averaged annual total AOD increased by $\sim 0.6-8.2 \%$ due to additional SOA formed in the MZ4-C2 simulation. The model predicted that AOD increased over areas where SOA also increased from the basecase prediction. For example, Australia, Indonesia and South America experienced $\sim 750, \sim 400$ and $\sim 300 \%$ increases in SOA, which contributed to increases in total AOD by $\sim 7.7,4.4$, and $6.2 \%$, respectively. Increased SOA resulted in a corresponding $\sim 2.3-8.2 \%$ increase in AOD over the Atlantic, Pacific and Indian oceans. The South Pacific Ocean 
Table 5. Regionally averaged base-case annual AOD and its increases due to additional SOA predicted by the updated version of MOZART-4 (MZ4-C2). Also, shown in parenthesis, is the range of monthly average increase in total AOD due to SOA.

\begin{tabular}{lrrr}
\hline & & Base case & MZ4-C2 \\
\hline Region & $\begin{array}{r}\text { Total } \\
\text { AOD }\end{array}$ & $\begin{array}{r}\text { POA and SOA } \\
\text { contributions to } \\
\text { total AOD } \%)\end{array}$ & $\begin{array}{r}\text { Increase in total } \\
\text { AOD attributed } \\
\text { to SOA (\%) }\end{array}$ \\
\hline Canada $\left(50-70^{\circ} \mathrm{N}, 125-60^{\circ} \mathrm{W}\right)$ & & 7 & $0.9(0.1-2.1)$ \\
USA $\left(25-50^{\circ} \mathrm{N}, 125-60^{\circ} \mathrm{W}\right)$ & 0.23 & 6 & $1.2(0.3-3)$ \\
Europe $\left(35-70^{\circ} \mathrm{N}, 10^{\circ} \mathrm{W}-45^{\circ} \mathrm{E}\right)$ & 0.32 & 5 & $0.6(0.1-1.8)$ \\
North Asia $\left(45-70^{\circ} \mathrm{N}, 60-150^{\circ} \mathrm{E}\right)$ & 0.60 & 7 & $0.6(0.1-1.4)$ \\
Southeast Asia $\left(10-45^{\circ} \mathrm{N}, 60-125^{\circ} \mathrm{E}\right)$ & 0.38 & 5 & $1.8(1.0-2.4)$ \\
Indonesia $\left(10^{\circ} \mathrm{S}-10^{\circ} \mathrm{N}, 90-150^{\circ} \mathrm{E}\right)$ & 0.62 & 21 & $4.4(1.1-15.7)$ \\
North Africa $\left(\mathrm{Eq}-30^{\circ} \mathrm{N}, 20^{\circ} \mathrm{W}-55^{\circ} \mathrm{E}\right)$ & 0.18 & 3 & $2.9(1.3-5.3)$ \\
South Africa $\left(40^{\circ} \mathrm{S}-\mathrm{Eq}, 0-55^{\circ} \mathrm{E}\right)$ & 0.73 & 19 & $2.8(1.3-8.2)$ \\
South America $\left(30^{\circ} \mathrm{S}-\mathrm{Eq}, 90-30^{\circ} \mathrm{W}\right)$ & 0.14 & 14 & $6.2(2.6-13.3)$ \\
Australia $\left(45-10^{\circ} \mathrm{S}, 110-160^{\circ} \mathrm{E}\right)$ & 0.15 & 9 & $7.7(3.6-30.4)$ \\
North Pacific Ocean $\left(\mathrm{Eq}-60^{\circ} \mathrm{N}, 135^{\circ} \mathrm{E}-100^{\circ} \mathrm{W}\right)$ & 0.20 & 6 & $2.3(1.2-3.2)$ \\
North Atlantic $\mathrm{Ocean}\left(\mathrm{Eq}-60^{\circ} \mathrm{N}, 0-80^{\circ} \mathrm{W}\right)$ & 0.39 & 3 & $2.9(1.5-3.4)$ \\
South Pacific Ocean $\left(45^{\circ} \mathrm{S}-\mathrm{Eq}, 150^{\circ} \mathrm{E}-80^{\circ} \mathrm{W}\right)$ & 0.08 & 6 & $8.2(4.5-17.6)$ \\
South Atlantic Ocean $\left(45^{\circ} \mathrm{S}-\mathrm{Eq}, 60^{\circ} \mathrm{W}-15^{\circ} \mathrm{E}\right)$ & 0.13 & 13 & $4.1(2.2-8.9)$ \\
Indian Ocean $\left(45^{\circ} \mathrm{S}-30^{\circ} \mathrm{N}, 30-150^{\circ} \mathrm{E}\right)$ & 0.24 & 7 & $4.1(2.2-6.9)$ \\
\hline
\end{tabular}

experienced the highest AOD increase of $8.2 \%$ predicted by MZ4-C2.

There has been little effort to evaluate AOD predicted by MOZART-4, with the exception of the Emmons et al. (2010) study. In that study, MODIS retrievals were used to evaluate predicted monthly average total AOD over major oceans for several years of retrievals/model simulations. Comparisons for 2006 showed that the modeled AOD fell within the variability bounds of retrieved total AOD for each region of interest. Predicted monthly average total AOD (the basecase MOZART-4 AOD in this work) agreed quite well with observations over the North Pacific Ocean, under-estimated AOD over the South Pacific, South Atlantic, and Indian oceans, and over-estimated AOD over the North Atlantic Ocean. In the current study, MZ4-C2 predicted $\sim 2-8 \%$ increases in the annual total AOD over these oceans, suggesting that the model updates bring the under-estimated monthly average AOD closer to observations, except over the North Atlantic Ocean where the base-case model already over-estimated AOD. The comparison between MZ4-C2 and Lee and Chung's (2013) best estimated AOD shows that the model in the current study slightly over-estimated AOD over land regions. Lee and Chung (2013) combined AOD measurements from AERONET, MISR, MODIS and GOCART data, and presented their best estimated AODs of 0.15-0.20, $0.13-0.30,0.3-0.8$ and $0.10-0.15$, over Indonesia, South America, North Africa, and Australia, respectively. As can be seen from Table 5, the updated model estimated AODs fall within the Lee and Chung (2013) ranges for these regions.

\section{Conclusions}

The secondary organic aerosol (SOA) module in the MOZART-4 global chemical transport model was updated by replacing the existing two-product $(2 \mathrm{p})$ parameters with those obtained from recent two-product volatility basis set (2p-VBS) fits (MZ4-C1), and by adding isoprene $\left(\mathrm{C}_{5} \mathrm{H}_{8}\right)$, propene $\left(\mathrm{C}_{3} \mathrm{H}_{6}\right)$ and lumped alkenes with $\mathrm{C}>3$ (BIGENE) as precursor VOCs (volatile organic compounds) contributing to SOA formation (MZ4-C2) in the current study. Comparisons were made between the model simulations (base case and the two modified cases, MZ4-C1 and MZ4-C2) and with other model predictions and ambient observations. The updates to the SOA model largely improved predictions of SOA mass concentrations at the surface relative to predicted in the base-case MOZART4 model. Relative to the base-case simulation, MZ4-C1 predicted higher concentrations in regions where anthropogenic emissions were dominant, while MZ4-C2 predicted higher concentrations in regions where biogenic emissions were dominant. The comparisons between modeled and measured OA (organic aerosol) at several rural and urban sites in the Northern Hemisphere showed that the updates to MOZART4 still resulted in underprediction of surface OA mass concentration at both rural and urban sites (Table S3). MZ4-C2, however, clearly showed significant improvements over the base-case and MZ4-C1 predictions as indicated by fractional bias (FB) calculations at both rural (MZ4-C2, FB: $-19 \%$ vs. MZ4-C1, FB: $-36 \%$ and base case, FB: $-40 \%$ ), and urban (MZ4-C2, FB: $-26 \%$ vs. MZ4-C1, FB: $-44 \%$ and base case, FB: $-50 \%)$ sites. 
The modifications to the SOA module in MOZART-4 are scientifically relevant and important for future studies utilizing MOZART-4, or chemical transport models with a similarly configured SOA module, including those directed at global SOA and total OA budget estimations and pollution source attribution. These modifications if adopted, will also lead to improvements in regional air quality models where MOZART output is used for boundary conditions.

Acknowledgements. This work was supported by the Cooley Family Fund for Critical Research of the Oregon Community Foundation and Research and Sponsored Projects, and the Institute of Sustainable Solutions at Portland State University.

Edited by: O. Boucher

\section{References}

Andreae, M. O. and Crutzen, P. J.: Atmospheric aerosols: Biogeochemical sources and role in atmospheric chemistry, Science, 276, 152-158, doi:10.1126/science.276.5315.1052, 1997.

Barsanti, K. C., Carlton, A. G., and Chung, S. H.: Analyzing experimental data and model parameters: implications for predictions of SOA using chemical transport models, Atmos. Chem. Phys. Discuss., 13, 15907-15947, doi:10.5194/acpd-13-159072013, 2013.

Barth, M. C., Rasch, P. J., Kiehl, J. T., Benkovitz, C. M., and Schwartz, S. E.: Sulfur chemistry in the National Center for Atmospheric Research Community Climate Model: Description, evaluation, features, and sensitivity to aqueous chemistry, J. Geophys. Res., 105, 1387-1415, 2000.

Brasseur, G. P., Hauglustaine, D. A., Walters, S., Rasch, P. J., Muller, J. F., Granier, C., and Tie, X. X.: MOZART, a global chemical transport model for ozone and related chemical tracers 1. Model description, J. Geophys. Res., 103, 28265-28289, doi:10.1029/98jd02397, 1998.

Chan, C. Y., Xu, X. D., Li, Y. S., Wong, K. H., Ding, G. A., Chan, L. Y., and Cheng, X. H.: Characteristics of vertical profiles and sources of $\mathrm{PM}_{2.5}, \mathrm{PM}_{10}$ and carbonaceous species in Beijing, Atmos. Environ., 39, 5113-5124, doi:10.1016/j.atmosenv.2005.05.009, 2005.

Chen, Q., Farmer, D. K., Schneider, J., Zorn, S. R., Heald, C. L., Karl, T. G., Guenther, A., Allan, J. D., Robinson, N., Coe, H., Kimmel, J. R., Pauliquevis, T., Borrmann, S., Poeschl, U., Andreae, M. O., Artaxo, P., Jimenez, J. L., and Martin, S. T.: Mass spectral characterization of submicron biogenic organic particles in the Amazon Basin, Geophys. Res. Lett., 36, L20806, doi:10.1029/2009g1039880, 2009.

Chin, M., Ginoux, P., Kinne, S., Torres, O., Holben, B. N., Duncan, B. N., Martin, R. V., Logan, J. A., Higuarish, A., and Nakajima, T.: Tropospheric aerosol optical thickness from the GOCART model and comparisons with satellite and sun photometer measurements, J. Atmos. Sci., 59, 461-483, 2002.

Chung, S. H. and Seinfeld, J. H.: Global distribution and climate forcing of carbonaceous aerosols, J.Geophys. Res., 107, 4407, doi:10.1029/2001jd001397, 2002.
Claeys, M., Wang, W., Ion, A. C., Kourtchev, I., Gelencser, A., and Maenhaut, W.: Formation of secondary organic aerosols from isoprene and its gas-phase oxidation products through reaction with hydrogen peroxide, Atmos. Environ., 38, 4093-4098, doi:10.1016/j.atmosenv.2004.06.001, 2004.

Clarisse, L., Fromm, M., Ngadi, Y., Emmons, L., Clerbaux, C., Hurtmans, D., and Coheur, P.-F.: Intercontinental transport of anthropogenic sulfur dioxide and other pollutants: An infrared remote sensing case study, Geophys. Res. Lett., 38, L19806, doi:10.1029/2011gl048976, 2011.

Dan, M., Zhuang, G. S., Li, X. X., Tao, H. R., and Zhuang, Y. H.: The characteristics of carbonaceous species and their sources in $\mathrm{PM}_{2.5}$ in Beijing, Atmos. Environ., 38, 3443-3452, doi:10.1016/j.atmosenv.2004.02.052, 2004.

Delfino, R. J., Sioutas, C., and Malik, S.: Potential role of ultrafine particles in associations between airborne particle mass and cardiovascular health, Environ. Health Persp., 113, 934-946, doi:10.1289/ehp.7938, 2005.

Donahue, N. M., Robinson, A. L., Stanier, C. O., and Pandis, S. N.: Coupled partitioning, dilution, and chemical aging of semivolatile organics, Environ. Sci. Technol., 40, 2635-2643, doi:10.1021/es052297c, 2006.

Duan, F. K., He, K. B., Ma, Y. L., Jia, Y. T., Yang, F. M., Lei, Y., Tanaka, S., and Okuta, T.: Characteristics of carbonaceous aerosols in Beijing, China, Chemosphere, 60, 355-364, doi:10.1016/j.chemosphere.2004.12.035, 2005.

Dunlea, E. J., DeCarlo, P. F., Aiken, A. C., Kimmel, J. R., Peltier, R. E., Weber, R. J., Tomlinson, J., Collins, D. R., Shinozuka, Y., McNaughton, C. S., Howell, S. G., Clarke, A. D., Emmons, L. K., Apel, E. C., Pfister, G. G., van Donkelaar, A., Martin, R. V., Millet, D. B., Heald, C. L., and Jimenez, J. L.: Evolution of Asian aerosols during transpacific transport in INTEX-B, Atmos. Chem. Phys., 9, 7257-7287, doi:10.5194/acp-9-7257-2009, 2009.

Emmons, L. K., Walters, S., Hess, P. G., Lamarque, J.-F., Pfister, G. G., Fillmore, D., Granier, C., Guenther, A., Kinnison, D., Laepple, T., Orlando, J., Tie, X., Tyndall, G., Wiedinmyer, C., Baughcum, S. L., and Kloster, S.: Description and evaluation of the Model for Ozone and Related chemical Tracers, version 4 (MOZART-4), Geosci. Model Dev., 3, 43-67, doi:10.5194/gmd3-43-2010, 2010.

Farina, S. C., Adams, P. J., and Pandis, S. N.: Modeling global secondary organic aerosol formation and processing with the volatility basis set: Implications for anthropogenic secondary organic aerosol, J. Geophys. Res., 115, D09202, doi:10.1029/2009jd013046, 2010.

Forster, P., Ramaswamy, V., Artaxo, P., Berntsen, T., Betts, R., Fahey, D. W., Haywood, J., Lean, J., Lowe, D. C., Myhre, G., Nganga, J., Prinn, R., Raga, G., Schulz, M., and Van Dorland, R.: Changes in Atmospheric Constituents and in Radiative Forcing. In: Climate Change 2007: The Physical Science Basis. Contribution of Working Group I to the Fourth Assessment Report of the Intergovernmental Panel on Climate Change, edited by: Solomon, S., Qin, D., Manning, M., Chen, Z., Marquis, M., Averyt, K. B., Tignor, M., and Miller, H. L., Cambridge University Press, Cambridge, United Kingdom and New York, NY, USA, 2007. 
Gilardoni, S., Vignati, E., Marmer, E., Cavalli, F., Belis, C., Gianelle, V., Loureiro, A., and Artaxo, P.: Sources of carbonaceous aerosol in the Amazon basin, Atmos. Chem. Phys., 11, 27472764, doi:10.5194/acp-11-2747-2011, 2011.

Goldstein, A. H. and Galbally, I. E.: Known and unexplored organic constituents in the earth's atmosphere, Environ. Sci. Technol., 41, 1514-1521, doi:10.1021/es072476p, 2007.

Goto, D., Takemura, T., and Nakajima, T.: Importance of global aerosol modeling including secondary organic aerosol formed from monoterpene, J. Geophys. Res., 113, D07205, doi:10.1029/2007jd009019, 2008.

Granier, C., Guenther, A., Lamarque, J., Mieville, A., Muller, J., Olivier, J., Orlando, J., Peters, J., Petron, G., Tyndall, G., and Wallens, S.: POET, a database of surface emissions of ozone precursors, available at: http://www.aero.jussieu.fr/projet/ ACCENT/POET.php (last access: August 2008), 2005.

Griffin, R. J., Cocker, D. R., Flagan, R. C., and Seinfeld, J. H.: Organic aerosol formation from the oxidation of biogenic hydrocarbons, J. Geophys. Res., 104, 3555-3567, doi:10.1029/1998jd100049, 1999.

Guenther, A., Karl, T., Harley, P., Wiedinmyer, C., Palmer, P. I., and Geron, C.: Estimates of global terrestrial isoprene emissions using MEGAN (Model of Emissions of Gases and Aerosols from Nature), Atmos. Chem. Phys., 6, 3181-3210, doi:10.5194/acp-63181-2006, 2006.

Guillaume, B., Liousse, C., Rosset, R., Cachier, H., Van Velthoven, P., Bessagnet, B., and Poisson, N.: ORISAM-TM4: a new global sectional multi-component aerosol model including SOA formation - Focus on carbonaceous BC and OC aerosols, Tellus B, 59, 283-302, doi:10.1111/j.1600-0889.2006.00246.x, 2007.

Hack, J. J.: Parameterization of moist convection in the National Center for Atmospheric Research community climate model (CCM2), J. Geophys. Res., 99, 5551-5568, doi:10.1029/93jd03478, 1994.

Hallquist, M., Wenger, J. C., Baltensperger, U., Rudich, Y., Simpson, D., Claeys, M., Dommen, J., Donahue, N. M., George, C., Goldstein, A. H., Hamilton, J. F., Herrmann, H., Hoffmann, T., Iinuma, Y., Jang, M., Jenkin, M. E., Jimenez, J. L., Kiendler-Scharr, A., Maenhaut, W., McFiggans, G., Mentel, Th. F., Monod, A., Prévôt, A. S. H., Seinfeld, J. H., Surratt, J. D., Szmigielski, R., and Wildt, J.: The formation, properties and impact of secondary organic aerosol: current and emerging issues, Atmos. Chem. Phys., 9, 5155-5236, doi:10.5194/acp-9-51552009, 2009.

Heald, C. L., Jacob, D. J., Park, R. J., Russell, L. M., Huebert, B. J., Seinfeld, J. H., Liao, H., and Weber, R. J.: A large organic aerosol source in the free troposphere missing from current models, Geophys. Res. Lett., 32, L18809, doi:10.1029/2005g1023831, 2005.

Heald, C. L., Jacob, D. J., Turquety, S., Hudman, R. C., Weber, R. J., Sullivan, A. P., Peltier, R. E., Atlas, E. L., de Gouw, J. A., Warneke, C., Holloway, J. S., Neuman, J. A., Flocke, F. M., and Seinfeld, J. H.: Concentrations and sources of organic carbon aerosols in the free troposphere over North America, J. Geophys. Res., 111, D23S47, doi:10.1029/2006jd007705, 2006.

Heald, C. L., Coe, H., Jimenez, J. L., Weber, R. J., Bahreini, R., Middlebrook, A. M., Russell, L. M., Jolleys, M., Fu, T.-M., Allan, J. D., Bower, K. N., Capes, G., Crosier, J., Morgan, W. T., Robinson, N. H., Williams, P. I., Cubison, M. J., DeCarlo, P. F., and Dunlea, E. J.: Exploring the vertical profile of atmo- spheric organic aerosol: comparing 17 aircraft field campaigns with a global model, Atmos. Chem. Phys., 11, 12673-12696, doi:10.5194/acp-11-12673-2011, 2011.

Henze, D. K. and Seinfeld, J. H.: Global secondary organic aerosol from isoprene oxidation, Geophys. Res. Lett., 33, L09812, doi:10.1029/2006g1025976, 2006.

Henze, D. K., Seinfeld, J. H., Ng, N. L., Kroll, J. H., Fu, T.-M., Jacob, D. J., and Heald, C. L.: Global modeling of secondary organic aerosol formation from aromatic hydrocarbons: highvs. low-yield pathways, Atmos. Chem. Phys., 8, 2405-2420, doi:10.5194/acp-8-2405-2008, 2008.

Herron-Thorpe, F. L., Mount, G. H., Emmons, L. K., Lamb, B. K., Chung, S. H., and Vaughan, J. K.: Regional air-quality forecasting for the Pacific Northwest using MOPITT/TERRA assimilated carbon monoxide MOZART-4 forecasts as a near realtime boundary condition, Atmos. Chem. Phys., 12, 5603-5615, doi:10.5194/acp-12-5603-2012, 2012.

Hess, M., Koepke, P., and Schult, I.: Optical properties of aerosols and clouds: The software package OPAC, Bull. Am. Meteorol. Soc., 79, 831-844, 1998.

Holtslag, A. A. M. and Boville, B. A.: Local versus nonlocal boundary-layer diffusion in a global climate model, J. Climate, 6, 1825-1842, 1993.

Horowitz, L. W., Walters, S., Mauzerall, D. L., Emmons, L. K., Rasch, P. J., Granier, C., Tie, X. X., Lamarque, J. F., Schultz, M. G., Tyndall, G. S., Orlando, J. J., and Brasseur, G. P.: A global simulation of tropospheric ozone and related tracers: Description and evaluation of MOZART, version 2, J. Geophys. Res., 108, 4784, doi:10.1029/2002jd002853, 2003.

Hoyle, C. R., Berntsen, T., Myhre, G., and Isaksen, I. S. A.: Secondary organic aerosol in the global aerosol - chemical transport model Oslo CTM2, Atmos. Chem. Phys., 7, 5675-5694, doi:10.5194/acp-7-5675-2007, 2007.

Hoyle, C. R., Myhre, G., Berntsen, T. K., and Isaksen, I. S. A.: Anthropogenic influence on SOA and the resulting radiative forcing, Atmos. Chem. Phys., 9, 2715-2728, doi:10.5194/acp-9-27152009, 2009

Jacob, D. J.: Heterogeneous chemistry and tropospheric ozone, Atmos. Environ., 34, 2131-2159, 2000.

Jiang, F., Liu, Q., Huang, X., Wang, T., Zhuang, B., and Xie, M.: Regional modeling of secondary organic aerosol over China using WRF/Chem, J. Aerosol Sci., 43, 57-73, doi:10.1016/j.jaerosci.2011.09.003, 2012.

Jimenez, J. L., Canagaratna, M. R., Donahue, N. M., Prevot, A. S. H., Zhang, Q., Kroll, J. H., DeCarlo, P. F., Allan, J. D., Coe, H., Ng, N. L., Aiken, A. C., Docherty, K. S., Ulbrich, I. M., Grieshop, A. P., Robinson, A. L., Duplissy, J., Smith, J. D., Wilson, K. R., Lanz, V. A., Hueglin, C., Sun, Y. L., Tian, J., Laaksonen, A., Raatikainen, T., Rautiainen, J., Vaattovaara, P., Ehn, M., Kulmala, M., Tomlinson, J. M., Collins, D. R., Cubison, M. J., Dunlea, E. J., Huffman, J. A., Onasch, T. B., Alfarra, M. R., Williams, P. I., Bower, K., Kondo, Y., Schneider, J., Drewnick, F., Borrmann, S., Weimer, S., Demerjian, K., Salcedo, D., Cottrell, L., Griffin, R., Takami, A., Miyoshi, T., Hatakeyama, S., Shimono, A., Sun, J. Y., Zhang, Y. M., Dzepina, K., Kimmel, J. R., Sueper, D., Jayne, J. T., Herndon, S. C., Trimborn, A. M., Williams, L. R., Wood, E. C., Middlebrook, A. M., Kolb, C. E., Baltensperger, U., and Worsnop, D. R.: Evolution of Organic Aerosols in the Atmosphere, Science, 326, 1525-1529, 
doi:10.1126/science.1180353, 2009.

Johnson, D., Utembe, S. R., Jenkin, M. E., Derwent, R. G., Hayman, G. D., Alfarra, M. R., Coe, H., and McFiggans, G.: Simulating regional scale secondary organic aerosol formation during the TORCH 2003 campaign in the southern UK, Atmos. Chem. Phys., 6, 403-418, doi:10.5194/acp-6-403-2006, 2006.

Kalnay, E., Kanamitsu, M., Kistler, R., Collins, W., Deaven, D., Gandin, L., Iredell, M., Saha, S., White, G., Woollen, J., Zhu, Y., Chelliah, M., Ebisuzaki, W., Higgins, W., Janowiak, J., Mo, K. C., Ropelewski, C., Wang, J., Leetmaa, A., Reynolds, R., Jenne, R., and Joseph, D.: The NCEP/NCAR 40-year reanalysis project, B. Am. Meteorol. Soc., 77, 437-471, doi:10.1175/15200477(1996)077<0437:tnyrp>2.0.co;2, 1996.

Kanakidou, M., Seinfeld, J. H., Pandis, S. N., Barnes, I., Dentener, F. J., Facchini, M. C., Van Dingenen, R., Ervens, B., Nenes, A., Nielsen, C. J., Swietlicki, E., Putaud, J. P., Balkanski, Y., Fuzzi, S., Horth, J., Moortgat, G. K., Winterhalter, R., Myhre, C. E. L., Tsigaridis, K., Vignati, E., Stephanou, E. G., and Wilson, J.: Organic aerosol and global climate modelling: a review, Atmos. Chem. Phys., 5, 1053-1123, doi:10.5194/acp-5-1053-2005, 2005.

Kavouras, I. G., Mihalopoulos, N., and Stephanou, E. G.: Formation of atmospheric particles from organic acids produced by forests, Nature, 395, 683-686, doi:10.1038/27179, 1998.

Kistler, R., Kalnay, E., Collins, W., Saha, S., White, G., Woollen, J., Chelliah, M., Ebisuzaki, W., Kanamitsu, M., Kousky, V., van den Dool, H., Jenne, R., and Fiorino, M.: The NCEP-NCAR 50-year reanalysis: Monthly means CD-ROM and documentation, B. Am. Meteorol. Soc., 82, 247-267, doi:10.1175/15200477(2001)082<0247:tnnyrm>2.3.co;2, 2001.

Kleinman, L. I., Springston, S. R., Daum, P. H., Lee, Y.-N., Nunnermacker, L. J., Senum, G. I., Wang, J., Weinstein-Lloyd, J., Alexander, M. L., Hubbe, J., Ortega, J., Canagaratna, M. R., and Jayne, J.: The time evolution of aerosol composition over the Mexico City plateau, Atmos. Chem. Phys., 8, 1559-1575, doi:10.5194/acp-8-1559-2008, 2008.

Lack, D. A., Tie, X. X., Bofinger, N. D., Wiegand, A. N., and Madronich, S.: Seasonal variability of secondary organic aerosol: A global modeling study, J. Geophys. Res., 109, D03203, doi:10.1029/2003jd003418, 2004.

Lamarque, J.-F., Kiehl, J. T., Hess, P. G., Collins, W. D., Emmons, L. K., Ginoux, P., Luo, C., and Tie, X. X.: Response of a coupled chemistry-climate model to changes in aerosol emissions: Global impact on the hydrological cycle and the tropospheric burdens of $\mathrm{OH}$, ozone and $\mathrm{NO}_{\mathrm{x}}$, Geophys. Res. Lett., 32, L16809, doi:10.1029/2005GL023419, 2005.

Lane, T. E., Donahue, N. M., and Pandis, S. N.: Simulating secondary organic aerosol formation using the volatility basis-set approach in a chemical transport model, Atmos. Environ., 42, 7439-7451, doi:10.1016/j.atmosenv.2008.06.026, 2008.

Lee, A., Goldstein, A. H., Kroll, J. H., Ng, N. L., Varutbangkul, V., Flagan, R. C., and Seinfeld, J. H.: Gas-phase products and secondary aerosol yields from the photooxidation of 16 different terpenes, J. Geophys. Res., 111, D17305, doi:10.1029/2006jd007050, 2006.

Lee, K. and Chung, C. E.: Observationally-constrained estimates of global fine-mode AOD, Atmos. Chem. Phys., 13, 2907-2921, doi:10.5194/acp-13-2907-2013, 2013.
Lee-Taylor, J., Madronich, S., Aumont, B., Baker, A., Camredon, M., Hodzic, A., Tyndall, G. S., Apel, E., and Zaveri, R. A.: Explicit modeling of organic chemistry and secondary organic aerosol partitioning for Mexico City and its outflow plume, Atmos. Chem. Phys., 11, 13219-13241, doi:10.5194/acp-1113219-2011, 2011.

Liao, H., Henze, D. K., Seinfeld, J. H., Wu, S., and Mickley, L. J.: Biogenic secondary organic aerosol over the United States: Comparison of climatological simulations with observations, J Geophys. Res., 112, D06201, doi:10.1029/2006jd007813, 2007.

Lin, G., Penner, J. E., Sillman, S., Taraborrelli, D., and Lelieveld, J.: Global modeling of SOA formation from dicarbonyls, epoxides, organic nitrates and peroxides, Atmos. Chem. Phys., 12, 47434774, doi:10.5194/acp-12-4743-2012, 2012.

Lin, P., Hu, M., Deng, Z., Slanina, J., Han, S., Kondo, Y., Takegawa, N., Miyazaki, Y., Zhao, Y., and Sugimoto, N.: Seasonal and diurnal variations of organic carbon in $\mathrm{PM}_{2.5}$ in Beijing and the estimation of secondary organic carbon, J. Geophys. Res., 114, D00G11, doi:10.1029/2008jd010902, 2009.

Lin, S. J. and Rood, R. B.: Multidimensional flux-form semiLagrangian transport schemes, Mon. Weather Rev., 124, 20462070, doi:10.1175/1520-0493(1996)124<2046:mffslt >2.0.co;2, 1996.

Liousse, C., Penner, J. E., Chuang, C., Walton, J. J., Eddleman, H., and Cachier, H.: A global three-dimensional model study of carbonaceous aerosols, J. Geophys. Res., 101, 1941119432,doi:10.1029/95jd03426, 1996.

Murphy, B. N. and Pandis, S. N.: Simulating the Formation of Semivolatile Primary and Secondary Organic Aerosol in a Regional Chemical Transport Model, Environ. Sci. Technol., 43, 4722-4728, doi:10.1021/es803168a, 2009.

Murphy, B. N., Donahue, N. M., Fountoukis, C., and Pandis, S. N.: Simulating the oxygen content of ambient organic aerosol with the 2D volatility basis set, Atmos. Chem. Phys., 11, 7859-7873, doi:10.5194/acp-11-7859-2011, 2011.

O'Donnell, D., Tsigaridis, K., and Feichter, J.: Estimating the direct and indirect effects of secondary organic aerosols using ECHAM5-HAM, Atmos. Chem. Phys., 11, 8635-8659, doi:10.5194/acp-11-8635-2011, 2011.

Odum, J. R., Hoffmann, T., Bowman, F., Collins, D., Flagan, R. C., and Seinfeld, J. H.: Gas/particle partitioning and secondary organic aerosol yields, Environ. Sci. Technol., 30, 2580-2585, doi:10.1021/es950943+, 1996.

Olivier, J., Peters, J., Granier, C., Petron, G., Müller, J., and Wallens, S.: Present and future surface emissions of atmospheric compounds, POET report \#2, EU project EVK2-1999-00011, available at: http://www.aero.jussieu.fr/projet/ACCENT/POET. php (last access: August 2008), 2003.

Pankow, J. F.: An absorption-model of the gas aerosol partitioning involved in the formation of secondary organic aerosol, Atmos. Environ., 28, 185-188, doi:10.1016/1352-2310(94)900949, 1994.

Pankow, J. F. and Barsanti, K. C.: The carbon numberpolarity grid: A means to manage the complexity of the mix of organic compounds when modeling atmospheric organic particulate matter, Atmos. Environ., 43, 2829-2835, doi:10.1016/j.atmosenv.2008.12.050, 2009. 
Park, M., Randel, W. J., Emmons, L. K., and Livesey, N. J.: Transport pathways of carbon monoxide in the Asian summer monsoon diagnosed from Model of Ozone and Related Tracers (MOZART), J. Geophys. Res., 114, D08303, doi:10.1029/2008jd010621, 2009.

Pathak, R. K., Presto, A. A., Lane, T. E., Stanier, C. O., Donahue, N. M., and Pandis, S. N.: Ozonolysis of $\alpha$-pinene: parameterization of secondary organic aerosol mass fraction, Atmos. Chem. Phys., 7, 3811-3821, doi:10.5194/acp-7-3811-2007, 2007.

Pfister, G. G., Emmons, L. K., Edwards, D. P., Arellano, A., G Sachse, and Campos, T.: Variability of springtime transpacific pollution transport during 2000-2006: the INTEX-B mission in the context of previous years, Atmos. Chem. Phys., 10, 13451359, doi:10.5194/acp-10-1345-2010, 2010.

Pope, C. A. and Dockery, D. W.: Health effects of fine particulate air pollution: Lines that connect, J. Air Waste Manage., 56, 709742, 2006.

Presto, A. A. and Donahue, N. M.: Investigation of alphapinene plus ozone secondary organic aerosol formation at low total aerosol mass, Environ. Sci. Technol., 40, 3536-3543, doi:10.1021/es052203z, 2006.

Rasch, P. J., Mahowald, N. M., and Eaton, B. E.: Representations of transport, convection, and the hydrologic cycle in chemical transport models: Implications for the modeling of shortlived and soluble species, J. Geophys. Res., 102, 28127-28138, doi:10.1029/97jd02087, 1997.

Robinson, N. H., Hamilton, J. F., Allan, J. D., Langford, B., Oram, D. E., Chen, Q., Docherty, K., Farmer, D. K., Jimenez, J. L., Ward, M. W., Hewitt, C. N., Barley, M. H., Jenkin, M. E., Rickard, A. R., Martin, S. T., McFiggans, G., and Coe, H.: Evidence for a significant proportion of Secondary Organic Aerosol from isoprene above a maritime tropical forest, Atmos. Chem. Phys., 11, 1039-1050, doi:10.5194/acp-11-1039-2011, 2011.

Russell, L. M.: Aerosol organic-mass-to-organic-carbon ratio measurements, Environ. Sci. Technol., 37, 2982-2987, doi:10.1021/es026123w, 2003.

Schwartz, J.: The effects of particulate air pollution on daily deaths: a multi-city case crossover analysis, Occup. Environ. Med., 61, 956-961, doi:10.1136/oem.2003.008250, 2004.

Simpson, D., Yttri, K. E., Klimont, Z., Kupiainen, K., Caseiro, A., Gelencser, A., Pio, C., Puxbaum, H., and Legrand, M.: Modeling carbonaceous aerosol over Europe: Analysis of the CARBOSOL and EMEP EC/OC campaigns, J. Geophys. Res., 112, D23S14, doi:10.1029/2006jd008158, 2007.

Slowik, J. G., Stroud, C., Bottenheim, J. W., Brickell, P. C., Chang, R. Y.-W., Liggio, J., Makar, P. A., Martin, R. V., Moran, M. D., Shantz, N. C., Sjostedt, S. J., van Donkelaar, A., Vlasenko, A., Wiebe, H. A., Xia, A. G., Zhang, J., Leaitch, W. R., and Abbatt, J. P. D.: Characterization of a large biogenic secondary organic aerosol event from eastern Canadian forests, Atmos. Chem. Phys., 10, 2825-2845, doi:10.5194/acp-10-2825-2010, 2010.

Spracklen, D. V., Jimenez, J. L., Carslaw, K. S., Worsnop, D. R., Evans, M. J., Mann, G. W., Zhang, Q., Canagaratna, M. R., Allan, J., Coe, H., McFiggans, G., Rap, A., and Forster, P.: Aerosol mass spectrometer constraint on the global secondary organic aerosol budget, Atmos. Chem. Phys., 11, 12109-12136, doi:10.5194/acp-11-12109-2011, 2011.
Tang, Y., Lee, P., Tsidulko, M., Huang, H.-C., McQueen, J. T., DiMego, G. J., Emmons, L. K., Pierce, R. B., Thompson, A. M., Lin, H.-M., Kang, D., Tong, D., Yu, S., Mathur, R., Pleim, J. E., Otte, T. L., Pouliot, G., Young, J. O., Schere, K. L., Davidson, P. M., and Stajner, I.: The impact of chemical lateral boundary conditions on CMAQ predictions of tropospheric ozone over the continental United States, Environ. Fluid Mech., 9, 43-58, doi:10.1007/s10652-008-9092-5, 2009.

Tie, X., Brasseur, G., Emmons, L., Horowitz, L., and Kinnision, D.: Effects of aerosols on tropospheric oxidants: A global model study, J. Geophys. Res., 106, 2931-2964, 2001.

Tie, X., Madronich, S., Walters, S., Edwards, D., Ginoux, P., Mahowald, N., Zhang, R., Luo, C., and Brasseur, G.: Assessment of the global impact of aerosols on tropospheric oxidants, J. Geophys. Res., 110, D03204, doi:10.1029/2004JD005359, 2005.

Tsigaridis, K. and Kanakidou, M.: Secondary organic aerosol importance in the future atmosphere, Atmos. Environ., 41, 46824692, doi:10.1016/j.atmosenv.2007.03.045, 2007.

Tsimpidi, A. P., Karydis, V. A., Zavala, M., Lei, W., Molina, L., Ulbrich, I. M., Jimenez, J. L., and Pandis, S. N.: Evaluation of the volatility basis-set approach for the simulation of organic aerosol formation in the Mexico City metropolitan area, Atmos. Chem. Phys., 10, 525-546, doi:10.5194/acp-10-525-2010, 2010.

Valorso, R., Aumont, B., Camredon, M., Raventos-Duran, T., Mouchel-Vallon, C., Ng, N. L., Seinfeld, J. H., Lee-Taylor, J., and Madronich, S.: Explicit modelling of SOA formation from $\alpha$-pinene photooxidation: sensitivity to vapour pressure estimation, Atmos. Chem. Phys., 11, 6895-6910, doi:10.5194/acp-116895-2011, 2011.

van der Werf, G. R., Randerson, J. T., Giglio, L., Collatz, G. J., Kasibhatla, P. S., and Arellano Jr., A. F.: Interannual variability in global biomass burning emissions from 1997 to 2004, Atmos. Chem. Phys., 6, 3423-3441, doi:10.5194/acp-6-3423-2006, 2006.

Volkamer, R., Jimenez, J. L., San Martini, F., Dzepina, K., Zhang, Q., Salcedo, D., Molina, L. T., Worsnop, D. R., and Molina, M. J.: Secondary organic aerosol formation from anthropogenic air pollution: Rapid and higher than expected, Geophys. Res. Lett., 33, L17811, doi:10.1029/2006g1026899, 2006.

Wespes, C., Emmons, L., Edwards, D. P., Hannigan, J., Hurtmans, D., Saunois, M., Coheur, P.-F., Clerbaux, C., Coffey, M. T., Batchelor, R. L., Lindenmaier, R., Strong, K., Weinheimer, A. J., Nowak, J. B., Ryerson, T. B., Crounse, J. D., and Wennberg, P. O.: Analysis of ozone and nitric acid in spring and summer Arctic pollution using aircraft, ground-based, satellite observations and MOZART-4 model: source attribution and partitioning, Atmos. Chem. Phys., 12, 237-259, doi:10.5194/acp-12-237-2012, 2012.

Zhang, Q., Canagaratna, M. R., Jayne, J. T., Worsnop, D. R., and Jimenez, J. L.: Time- and size-resolved chemical composition of submicron particles in Pittsburgh: Implications for aerosol sources and processes, J. Geophys. Res., 110, D07S12, doi:10.1029/2004jd004649, 2005.

Zhang, Q., Jimenez, J. L., Canagaratna, M. R., Allan, J. D., Coe, H., Ulbrich, I., Alfarra, M. R., Takami, A., Middlebrook, A. M., Sun, Y. L., Dzepina, K., Dunlea, E., Docherty, K., DeCarlo, P. F., Salcedo, D., Onasch, T., Jayne, J. T., Miyoshi, T., Shimono, A., Hatakeyama, S., Takegawa, N., Kondo, Y., Schneider, J., Drewnick, F., Borrmann, S., Weimer, S., Demer- 
jian, K., Williams, P., Bower, K., Bahreini, R., Cottrell, L., Griffin, R. J., Rautiainen, J., Sun, J., Y., Zhang, Y. M., and Worsnop, D. R.: Ubiquity and dominance of oxygenated species in organic aerosols in anthropogenically-influenced Northern Hemisphere midlatitudes, Geophys. Res. Lett., 34, L13801, doi:10.1029/2007GL029979, 2007.
Zhang, X. Y., Wang, Y. Q., Niu, T., Zhang, X. C., Gong, S. L., Zhang, Y. M., and Sun, J. Y.: Atmospheric aerosol compositions in China: spatial/temporal variability, chemical signature, regional haze distribution and comparisons with global aerosols, Atmos. Chem. Phys., 12, 779-799, doi:10.5194/acp12-779-2012, 2012. 